Gravettian portable art on lithic support from Isturitz cave (Saint-Martin-d'Arberoue, PyrénéesAtlantiques, France) : a rediscovered collection

L'art mobilier gravettien sur support lithique de la grotte d'Isturitz (Saint-

Martin-d'Arberoue, Pyrénées-Atlantiques, France) : une collection redécouverte

\title{
Olivia Rivero and Diego Garate
}

\section{OpenEdition}

\section{Journals}

\section{Electronic version}

URL: http://journals.openedition.org/paleo/3016

DOI: 10.4000/paleo.3016

ISSN: 2101-0420

\section{Publisher}

SAMRA

\section{Printed version}

Date of publication: 28 December 2014

Number of pages: $247-276$

ISSN: $1145-3370$

\section{Electronic reference}

Olivia Rivero and Diego Garate, « Gravettian portable art on lithic support from Isturitz cave (SaintMartin-d'Arberoue, Pyrénées-Atlantiques, France) : a rediscovered collection », PALEO [Online], 25 | 2014, Online since 28 July 2015, connection on 07 July 2020. URL : http://journals.openedition.org/ paleo/3016 ; DOI : https://doi.org/10.4000/paleo.3016

This text was automatically generated on 7 July 2020. 


\title{
Gravettian portable art on lithic support from Isturitz cave (Saint- Martin-d'Arberoue, Pyrénées- Atlantiques, France) : a rediscovered collection
}

\author{
L'art mobilier gravettien sur support lithique de la grotte d'Isturitz (Saint- \\ Martin-d'Arberoue, Pyrénées-Atlantiques, France) : une collection redécouverte
}

\section{Olivia Rivero and Diego Garate}

We wish to thank Catherine Schwab and Marie-Sylvie Larguèze from the National Archaeology Museum of Saint-Germain-en-Laye for access to the studied material and J. Darricau, owner of Isturitz cave, for her support and encouragement for the advancement of research. We also thank the reviewers of this paper for their advice and Ch. Normand for his useful comments on the stratigraphy of Isturitz. Finally, thank you to the art study team of the hill of Gaztelu for their collaboration. This study was funded by the Regional Archaeology Service (DRAC Aquitaine).

1 Isturitz cave is part of a series of caves located in the hill of Gaztelu (municipalities of Isturitz and Saint-Martin-d'Arberoue, Pyrenees-Atlantiques), a major site for European prehistory (fig. 1). Archaeological research has focused on the caves of Isturitz, Oxocelhaya-Hariztoya and Erberua.

2 Isturitz cave, globally oriented northwest/southeast, was probably originally a very vast tunnel, over 120 meters long by locally up to $50 \mathrm{~m}$ wide, opened at both ends. Successive collapses gradually filled the south-eastern entrance, through which the Arberoue River penetrated, and drastically reduced the entrance at the opposite end. According to the various observations carried out, the corresponding porches must have had imposing dimensions. In the early Middle Palaeolithic, the porch would have been between 15 and $20 \mathrm{~m}$ wide and nearly $10 \mathrm{~m}$ high. Such an opening was necessarily 
visible from a distance and must have attracted the prehistoric populations visiting the valley from a very early time. In historic times, only the entrance located on the municipality of Isturitz was accessible. This fact is at the origin of the name of the cave, although the larger part of the karst network belongs to the municipality of SaintMartin-d'Arberoue.

The cave is commonly divided into two: the Saint Martin Chamber (or Southern Chamber) and the Grande SalleGrande Salle or Isturitz Chamber (or Northern Chamber). Two annex chambers can be added: the Rhinolophes Chamber and the Phosphates Chamber, as well as various small adjacent galleries connecting the different sectors.

Isturitz Chamber is impressive by its scale with a surface of over $1,500 \mathrm{~m}^{2}$, highlighted by a ceiling height up to $15 \mathrm{~m}$ locally. Currently, the floor has a double gradient, due to its two ends, converging near the stairs dug in 1953 to provide access to the Oxocelhaya network. The maximum gradient, at the entrance on Isturitz side corresponds to a major bank, now formed by the waste from ancient excavations. The slope seems to be very close to what existed previously. Remains of floors still attached to the walls show a significant calcite covering destroyed during these excavations. Moreover, this part must have been cluttered with bulky collapsed blocks described by the early excavators. The slope near the Rhinolophes Chamber, where research only consisted in some test pits, still has the stalagmite cover disappeared elsewhere. In its eastern extension, a low passage, where limestone surfaced under a few tens of centimetres of sediment, leads to Saint-Martin Chamber, whose appearance, much less affected by previous excavations, is significantly different. In addition to a smaller area, it differs from its neighbour by a vault barely exceeding $2 \mathrm{~m}$ high and by numerous concretions connecting the ceiling to a floor, locally over $0.30 \mathrm{~m}$ thick. It is destroyed only in the part near the Phosphates Chamber and inside two galleries, respectively ten and twenty meters long, which open near the South-eastern, entrance (Normand 2005/2006).

Inside Isturitz cave, several decades of excavations in the twentieth century have revealed a very important stratigraphy covering the Middle Palaeolithic and the entire Upper Palaeolithic. In 1912, excavations began under the direction of E. Passemard until 1922 (Passemard 1944). The Count and Countess de Saint Périer resumed the work until 1959 (Saint-Perier, Saint-Perier 1930, 1936, 1952). From 1996, research started again at the initiative of the Regional Service of Archaeology of Aquitaine. After a sounding campaign showing a very strong archaeological potential (Normand, Turq 2006), an excavation operation was set up in 1999 in the Saint Martin Chamber. This operation was continued from 2000 until 2010 under the direction of C. Normand (Normand 2005/2006).

6 In 2011, a new team led by D. Garate resumed the study of the parietal art of the Hill (Garate et al. 2013). As part of this research, the revision of the portable art was resumed again by 0 . Rivero, especially for the levels corresponding to the Early and Middle Upper Palaeolithic. 
Figure 1 - Situation of Isturitz cave (the red spots are the Upper Palaeolithic sites).

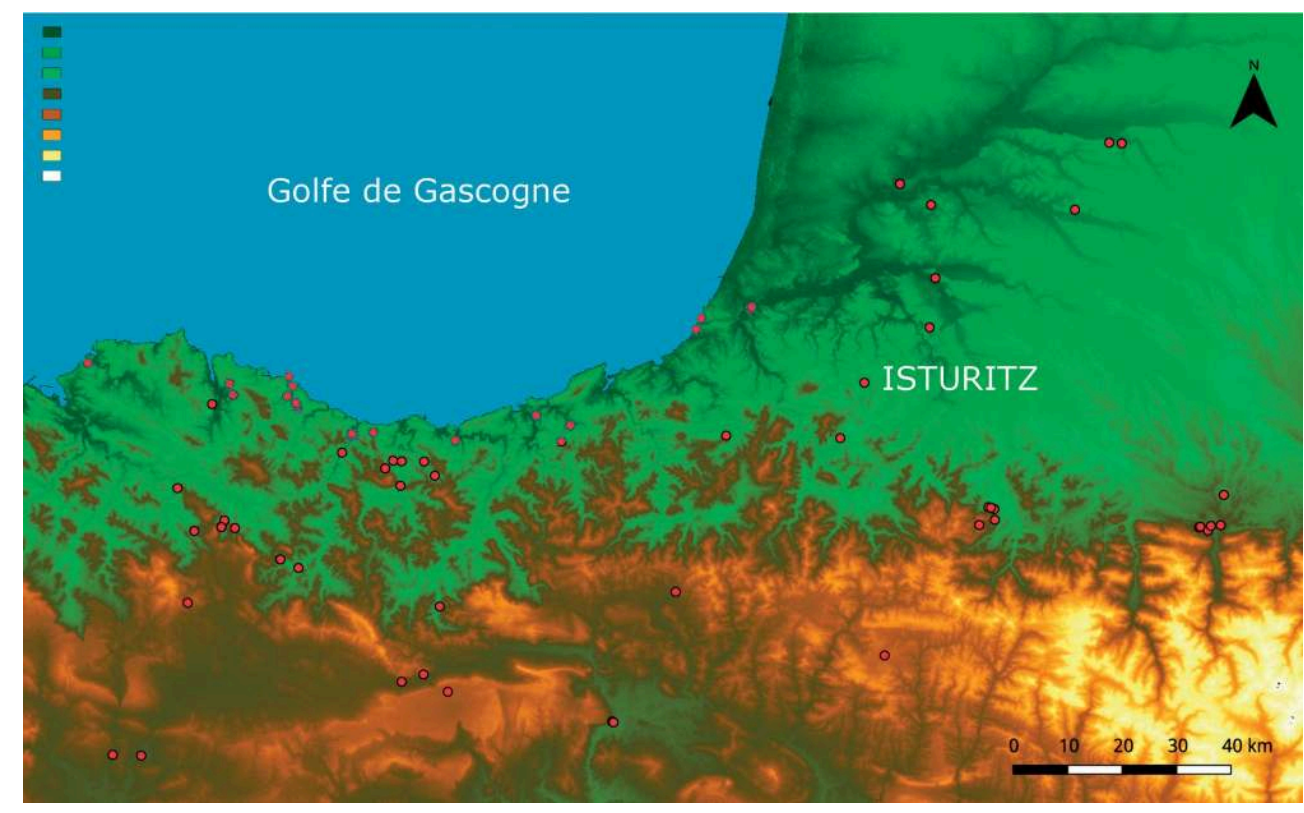

\section{1 - The Gravettian occupation of the cave}

7 The stratigraphy of Isturitz site is complex because of its spatial extent and its long diachrony, but also because of a knowledge deficit, caused by over intense and premature excavations.

\section{1 - E. Passemard's excavations}

E. Passemard's excavations focused on the Grande Salle (or Northern) since their beginning in 1912 until 1922. He considered that it was the richest area of the cave, archaeologically speaking. He excavated around the Engraved Pillar, where he reached the Gravettian occupations (and part of the Aurignacian), over an area of about $15 \times 10$ $\mathrm{m}$, while nearby, only the Magdalenian levels were excavated. He differentiated two Gravettian levels with quite similar sedimentary characteristics. The FIII level had many faunal remains, mainly large bovines, and bowl-shaped hearths. The remains of lithic and bone industry were also abundant.

Above, level $\mathrm{C}$ is not particularly differentiated from the prior one. The hearths were still present, but were greyish and not black, and the fauna was much less abundant. The first manifestations of art in the Chamber were in this level. E. Passemard noted "several pebbles and plaquettes of various more or less hard rock (that) bear lines; almost all are only traces of rectilinear cutting and are intersecting, but however two are engraved with sinuous lines, quite undecipherable "(1944: 37) ${ }^{3 .}$

After level C, a clay layer in the middle part of the chamber has been interpreted as a lake sealing the Gravettian occupation. Two flood episodes separated by a thin settlement layer containing hearths and rich in industries and fauna, were called FII. It seems that these episodes were not observed in the St. Martin Chamber and they are small in the entrance and the inner area of the Grande Salle. 
11 In Saint Martin's Chamber, the intervention of E. Passemard was less important. He excavated an 8 by $3 \mathrm{~m}$ area at the back of the chamber to a depth of $7.5 \mathrm{~m}$. He describes an exceedingly poor gray layer without cultural attribution that, finally, thanks to some lithic pieces, was determined into two sublevels ( $\mathrm{x}$ and $\mathrm{y}$ ) "contemporary of the beautiful Aurignacian layers, middle and upper, of the North Room " (1944: 25). He locates the plaquette with a figurative engraving interpreted as a possible bison or mammoth hindquarters in this level (Passemard 1930: 359).

\section{2 - R. and S. Saint Perier's excavations}

12 The Saint-Perier's excavations took place between 1928 and 1952 in both chambers and on a larger area than their predecessor. After some preliminary test pits, they excavated almost the entire Magdalenian of Saint Martin Chamber between 1928 and 1929 (Saint-Perier, Saint-Perier 1930). They then continued the excavation of the Magdalenian layers of the Grande Sallebetween 1930 and 1935 (Saint-Perier, SaintPerier 1936). After 1935, they focused on the excavation of the underlying layers, already well dug up before (Saint-Perier, Saint-Perier 1952). Finally, in 1955 and 1956, J.-M. Barandiaran, G. Laplace and P. Boucher conducted surveys in the porch of the Saint-Martin entrance, under the direction of S. Saint-Perier.

13 In Saint Martin's chamber, these results differed from E. Passemard's. Under these Magdalenian layers, two Solutrean points were found, but no item is attributable to the Gravettian, the Aurignacian levels lying immediately below.

In Isturitz Chamber, their stratigraphy corresponds to E. Passemard's observations The lower level, IV, about 50 to $60 \mathrm{~cm}$ thick, was particularly rich in archaeological remains, "flint and bones appeared even to the less knowledgeable onlooker with startling abundance, touching each other on meters in extent and forming here and there compact clusters at the bottom of the hearth pits, marked with an even blacker arch or highlighted by fire-reddened pebbles (Saint-Perier, Saint-Perier 1952: 80 )."

The upper level, III, 50 to $80 \mathrm{~cm}$ thick, was in continuity without intermediate episode, but it was archaeologically poorer. The layer was "as dry as the previous was wet, made more of black ashes than soil, packed with bone fragments, constituting a black mass dotted with red and yellow" (Saint-Perier, Saint-Perier 1952: 80).

\section{3 - C. Normand's surveys and excavations}

16 The surveying campaign conducted between 1996 and 1998 to assess the remaining archaeological potential, was directed by A. Turq and C. Normand. The research revealed that only about ten square meters of the control section left in the Isturitz Chamber by R. and S. de Saint-Perier was intact, and a small area next to the tunnels that connect the two main chambers. Clearing work of the waste from the old excavations in the Isturitz Chamber (fig. 2) confirmed the existence of a reversed sequence with an oily and yellowish clay layer, which would correspond to E. Passemard's level C and to R. and S. de Saint-Perier's level III, and of another, lighter and black, which is E. Passemard's level F3 and R. and S. de Saint-Perier's level IV (Lacarrière et al. 2011). Later, the excavations done by C. Normand between 1999 and 2010 focused on the first levels of the Upper Palaeolithic of Saint-Martin Chamber (Normand 2005/2006). 


\section{4 - Critical review}

from both levels F III and III, as well as an engraved pebble from both the Solutrean level IIIa and the Gravettian level IV, highlight stratigraphic reading errors (Bush 1990). The study of the compressors, the human remains and the bone industry also showed interlayer connections, particularly in levels II and III, in some cases confirmed by radiocarbon dating (Gambier 1990-1991; Beaune 1997; Goutas 2004; Pétillon 2004, 2006; Szmidt et al. 2009; Henry-Gambier, Pétillon, Normand 2013). These contaminations correspond to the difficulties of the Saint-Periers to individualize the upper level of the Gravettian (III) from the Solutrean level (IIIa). The identification of two "benches" was more intuitive, systematic and confirmed later by observing differences in the series. For level IV, Gravettian elements can be found in other layers, but the opposite is rare. A quick review of the lithic assemblage confirms that the contamination of level IV is consistent with a loss of part of the collection. If we can find Gravettian backed elements in the Solutrean, there seems to be no Solutrean contamination in the level IV. It shows that the lower level of the Gravettian seems very homogeneous (Simonet, 2009).

In Saint Martin's Chamber, the view is very different for the Gravettian occupation. E. Passemard indicates indeed the discovery of elements of Gravettian aspect in the upper part of the layer $\mathrm{X}$ and $\mathrm{Y}$. They would correspond to FIII layer in Isturitz Chamber. The Saint-Periers, meanwhile, did not identify a layer that could correspond to the Gravettian levels. Their SII layer, which is above a first Aurignacian level SIII, contains an exclusively Aurignacian industry. Some authors have argued for an Aurignacian attribution for the X and Y level (Esparza, San Juan 1995), while others consider it to be a mixture of ephemeral Gravettian and Aurignacian occupations (Lacarrière et al. 2011). It was even noticed that there appeared to be no Gravettian occupation in Saint Martin Chamber. The $\mathrm{X}$ and $\mathrm{Y}$ levels would rather be a secondary deposit (thus a mixture) through a contribution by water from the Grande Salle, rather than an archaeological level in place (Simonet 2009). 
Figure 2 - Excavated Gravettian surface in Isturitz cave (Normand et al. 2012).

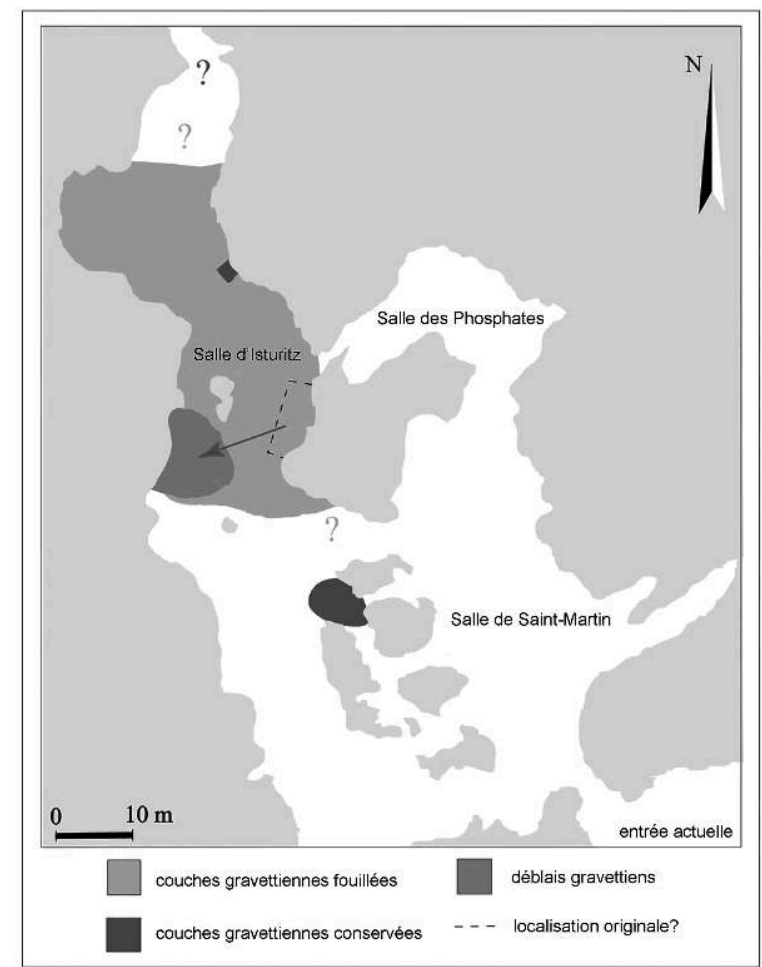

\section{2 - The Passemard and Saint-Perier collections of pre-Magdalenian portable art}

21 The portable art of Isturitz cave has been widely known since E. Passemard and R. and S. de Saint-Perier's researches. Many studies focused in particular on the Magdalenian series, most abundant and most spectacular (Mons 1986, 1986-1987; Rivero 2010, 2014; Lucas 2012; Croidieu 2012). The revisions also affected part of the portable art on hard animal materials from the Gravettian series, by C. San Juan-Foucher (San Juan, Foucher 2012) and on pebbles, some being engraved (Beaune 1997).

Nevertheless, the group of the pre-Magdalenian works of art from Isturitz remains unknown since the publications of E. Passemard and R. Saint-Perier. As part of a revision of the parietal and portable art of the site, we have undertaken the study of objects kept in the Museum of National Archaeology of Saint-Germain-en-Laye, where both collections are found.

The presence of portable art from the early and middle Upper Palaeolithic has previously been reported by E. Passemard (1944), who published three objects on lithic support, but Saint-Perier's count remains the reference: "about ten plaquettes and pebbles of schist, sandstone or limestone, bear engravings, which for the most part, are decipherable with difficulty because of their entanglement, their layering, their fragmented nature, and whose quality is generally mediocre when one manages to decipher them "(Saint-Perier, Saint-Perier 1952: 30-31). 
We will see that the description and identification of animal figures on these lithic supports are in general very imprecise and mostly wrong, due to the complexity of the compositions.

We have focused our interest on the lithic collection as the portable art on osseous support has been the subject of a recent review by C. San Juan (San Juan 2012). We are presenting here a first assessment of the identified animal figurative representations ${ }^{4}$. They are 23 decorated objects among which we identified 57 animal figures and 5 doubtful representations.

\section{1 - Inventory of the objects}

\section{R. and S. de Saint-Perier collection ${ }^{5}$}

\section{Ist.II. without number (published as IIIa) $\left(n^{\circ} 23\right)^{6}(\mathrm{fig} .3)$}

Fragmented limestone plaquette engraved on one of its two faces.

On one side, the possible hindquarters of a quadruped were represented. The pattern has been engraved through several incisions, which had led R. de Saint-Perier to interpret the pattern as equivalent to the engravings known as "striated engraving" typical of the Cantabrian Lower Magdalenian. However, his interpretation of the pattern as a doe's head can not be accepted. The stratigraphic origin of the plaquette is not certain, because of the acronym problem (marked as Ist.II on one side and Ist.I on the other, and published as Ist.IIIa). These data lead us to remain very cautious about the analogy drawn by R. de Saint-Perier, which, in light of current data, cannot be accepted.

Figure 3 - Slab Ist.II. Without number $\left(n^{\circ} 23\right)$. Photograph and tracing of the engraved figures.

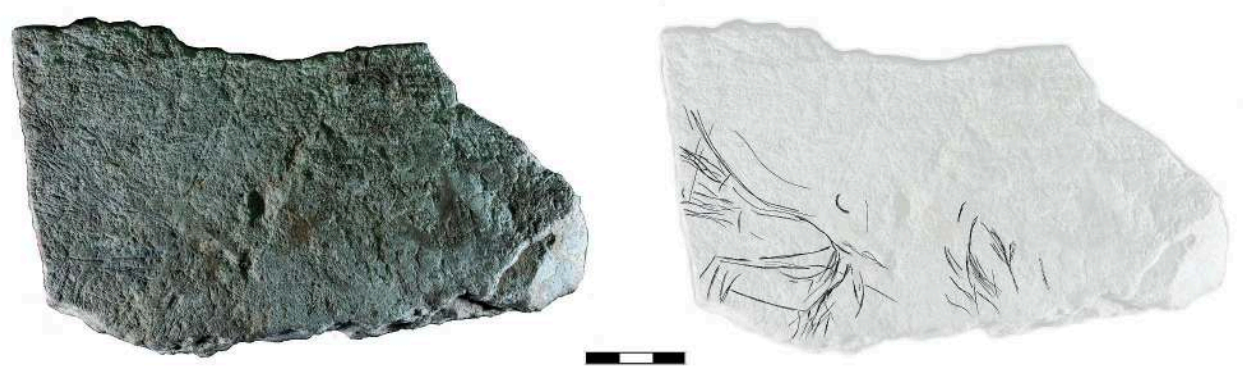

Ist.IIIa. MAN 84846 - Ist.IV. MAN 84875 (fig. 4)

Fragmented pebble, for which the two recovered fragments come from two different layers, level IIIa, assumed Solutrean, and level IV, Gravettian. The pebble is decorated on both sides. It shows traces of use as a compressor on both sides and a deep groove on the upper side (sharpener?). Sophie de Beaune (1997: 33) also proposes a re-fitting with the Ist.III.S / N.09 pebble. However, the fragmentary state and the small size of the breakage do not allow certifying it.

The upper side, despite the fragmentation of the support, shows the lower part of a quadruped, the line of the chest, the two front legs, the line of the abdomen and the rear legs being visible. A line of hatches could be part of another figurative 
representation (bison?) lost with the fracture of the support. Other lines can be linked to the grooving, and thus be part of the now lost patterns.

The lower side shows a bison head; only the forehead line, the eye and the horns are preserved. In inverted position with respect to this figure is the lower part of a quadruped with both front legs, the line of the chest, the line of the abdomen, the two rear legs and the buttocks line being figured. A double curved line, associated with hatching, may correspond to a figure of bison with a hatched bump, its cervical-dorsal line and the beginning of the line of the rump. Other lines, including hatches and curved lines most likely correspond to other figures (three bison?).

Figure 4 - Pebble Ist.IIla. MAN 84846 - Ist.IV. MAN 84875. Photograph and tracing of the engraved figures.

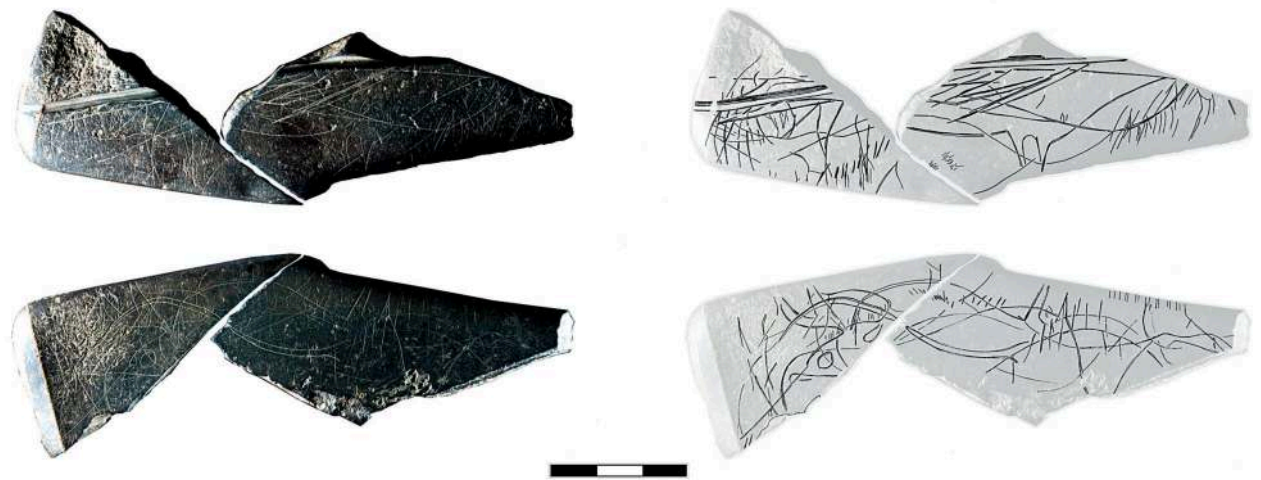

Ist.IIIa. without number (11) (fig. 5)

Fragmented Pebble, engraved on both sides, with negative of removals, impregnated with ochre (before and after engraving).

The upper surface has a very high number of figures entangled in all directions, some of which are incomplete and others unreadable.

Among the figures that can be distinguished, there are three bison, one aurochs, a small indeterminate animal and several hindquarters and isolated legs that correspond to figures of incomplete bovine and deer (fig. 6).

On the lower side, two figures of head-to-tail mammoths were represented, as well as two possible incomplete bovines.

The figures of both sides, even incomplete, present a very high number of details: eyes, nostrils, hatching for the beard, legs with hooves (cloven for deer), the anal flap in the case of mammoths, genitals in the case of bovines. These same conventions are found on other figurations on plaquettes from the Gravettian levels, as we shall see later. On both sides, the engravings are superimposed to the negatives of the extractions. 
Figure 5 - Pebble Ist.Illa. Without number ( $\left.n^{\circ} 11\right)$. Photograph and tracing of the engraved figures.
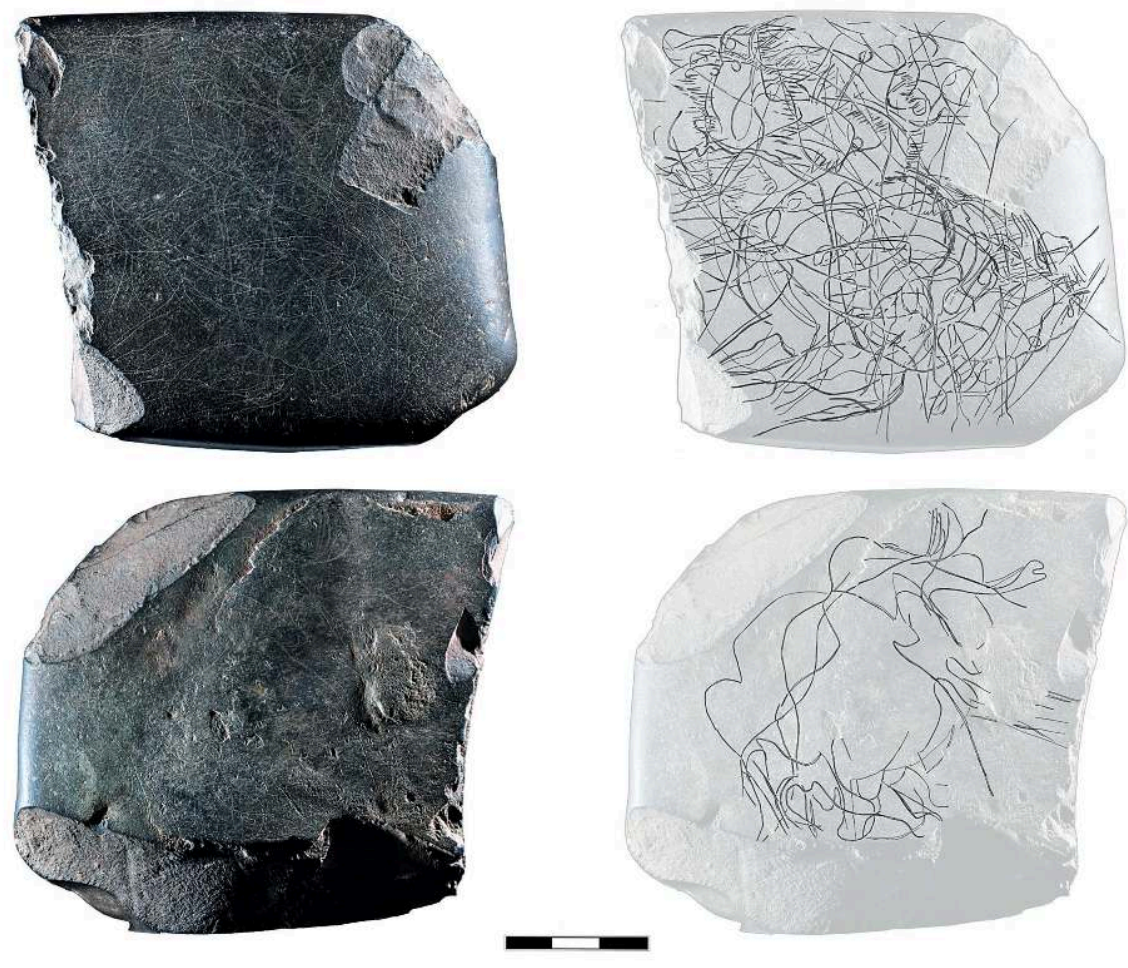

Figure 6 - Pebble Ist.IIla. Without number $\left(n^{\circ} 11\right)$. Tracing of some figures identified in the upper and lower sides.
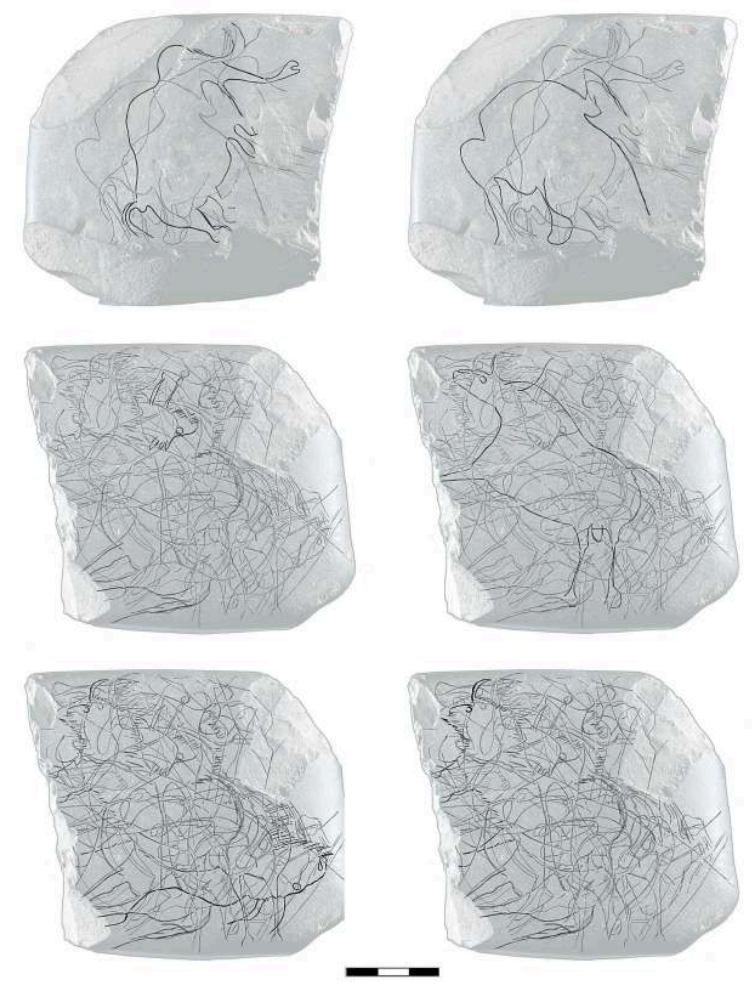
Ist.III. MAN 84847 (fig. 7)

Sandstone fragment, engraved on one side. A quadruped's hindquarters, probably equine, were represented by very deep engravings. The fragment retains only the end of the cervical-dorsal line, the tail, the line of the buttocks and the beginning of the hind leg.

Figure 7 - Slab Ist.III. MAN 84847. Photograph and tracing of the engraved figures.

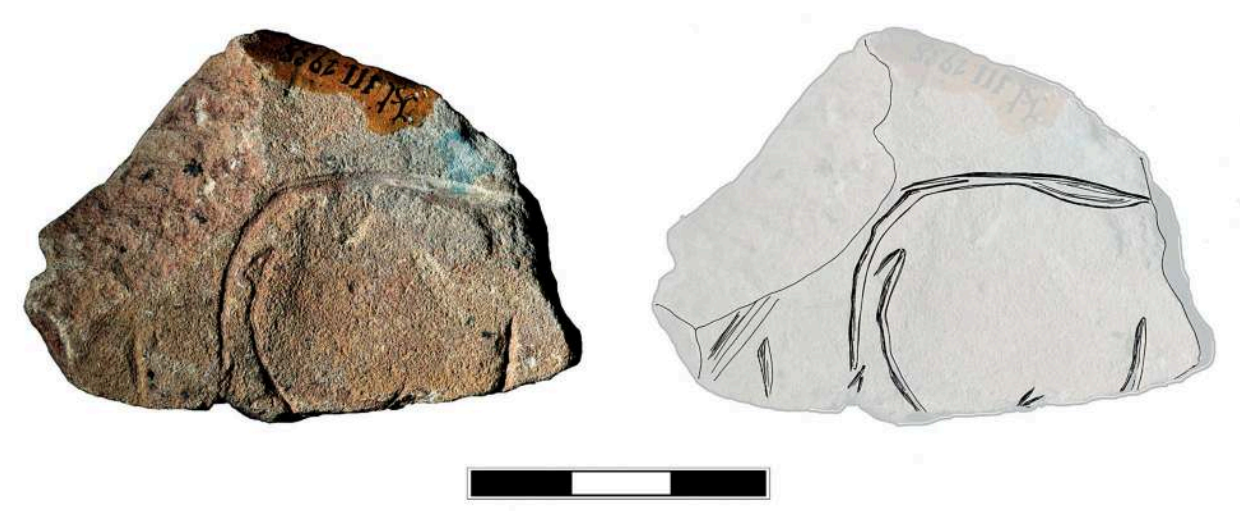

\section{Ist.III. MAN 84848 (fig. 8, 9)}

Pebble engraved on both faces, fragmented with negatives of removals, which shaped a crest impregnated with ochre, on which are superimposed part of the engravings. Both sides are abraded and show traces of pecking.

The upper side has three intertwined and opposite bison figures that occupy all the available space. The two most complete figures are strictly superimposed in the same direction. There is a bison with two horns in frontal perspective, with mouth, linear beard projected forward, chest, front and rear legs in frontal view, with the hock indicated, cervical-dorsal line, animated tail superimposed to the buttocks (fig. 9.1). The second bison has only a horn, the head with the eye and mouth, hatched beard and bump, also hatched front legs to represent the coat, belly and hind legs in frontal perspective with hollow of the knee indicated, the cervical-dorsal line and the tail (fig. 9.2).

Opposed and reversed to these two figures, a third bison, incomplete, was engraved. It presents the cervical-dorsal line, two horns in frontal perspective, a double line of hump, probably because of a correction, the tail, the back legs in frontal perspective and the belly (fig. 9.3).

40 The formal differences between these three bison are remarkable, particularly in the treatment of the coat, which reflects two manners of drawings that recurred later, especially in the Magdalenian (Rivero 2009).

On the lower side, only one bison was represented. It has two horns in frontal perspective, a head whose muzzle is lost due to the fracture of the support, an eye, the hatched beard and bump, two front legs, stomach line, a rear leg with the hock indicated, cervical-dorsal line, tail, line of the rump. The extreme sinuosity of the ventral and cervical-dorsal lines may be mentioned in this figure. 
Figure 8 - Pebble Ist.III. MAN 84848. Photograph and tracing of the engraved figures.

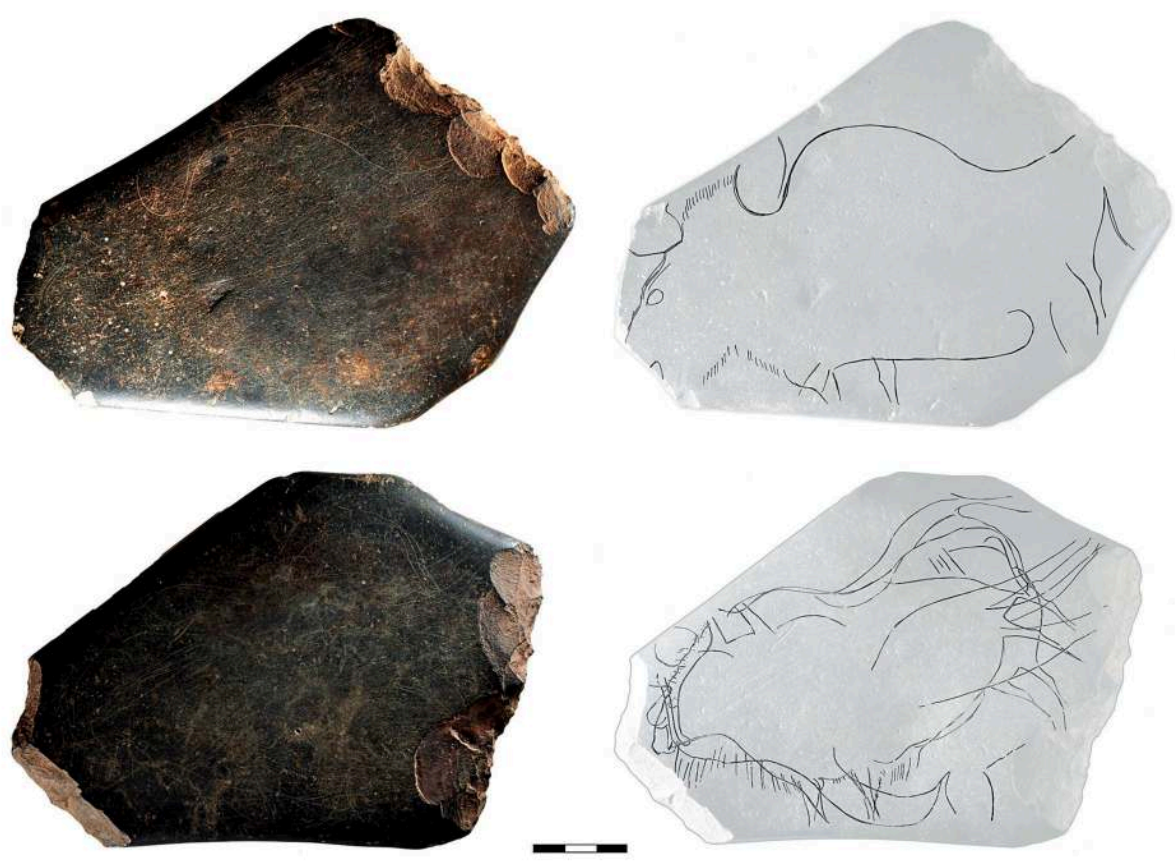

Figure 9 - Pebble Ist.III. MAN 84848. Tracing of the figures identified in the upper side.
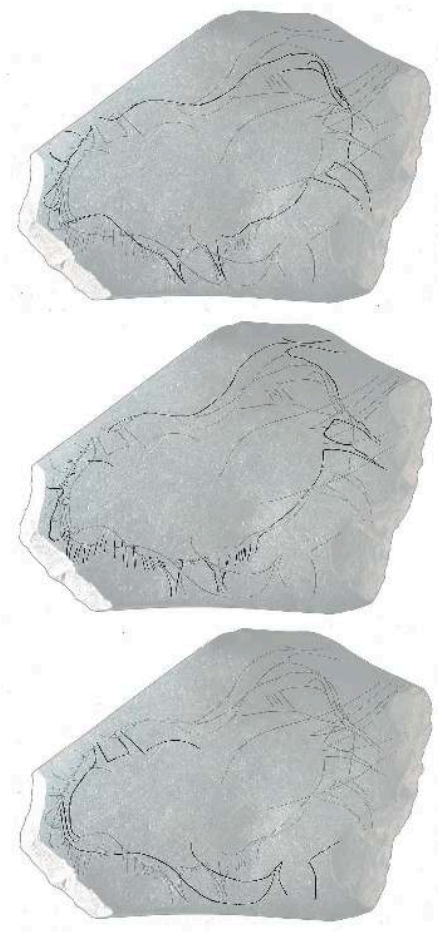

Ist.III. MAN 84856 (fig. 10)

42 Sandstone plaquette, impregnated with ochre on one of its faces and subsequently engraved. 
A possible bovine figure was engraved in fine incisions. It has the cervical-dorsal line, the rear leg, stomach line, horns and head. An indeterminate quadruped is superimposed on it, with the cervical-dorsal line, the line of the chest, front leg, stomach line and back leg. The figures were engraved so that, thanks to the ochre layer, they stood out on white in the painted background.

Figure 10 - Slab Ist.III. MAN 84856. Photograph and tracing of the engraved figures.

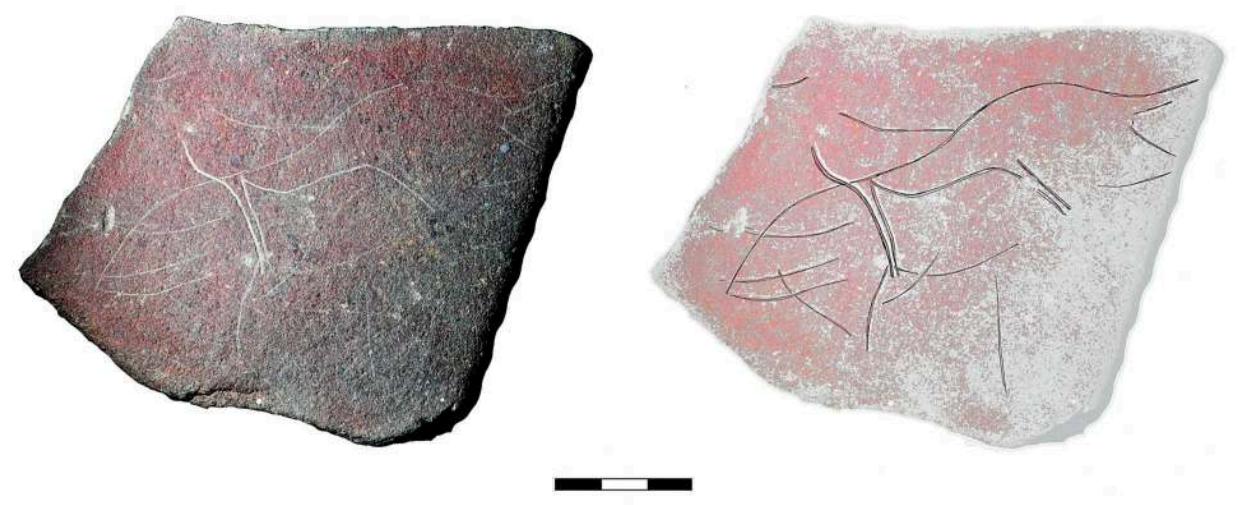

\section{Ist.III. MAN 84858 (fig. 11)}

Fragmented pebble with impact remains on the lower part. It is pecked on one side and abraded on the other and bears remains of ochre in the cupmarks.

The pebble was engraved on its upper face. The pattern, despite the fragmentary state of the support, shows a very massive animal figure whose two legs, belly and a small part of the cervical-dorsal line are visible.

Figure 11 - Pebble Ist.III. MAN 84858. Photograph and tracing of the engraved figures.

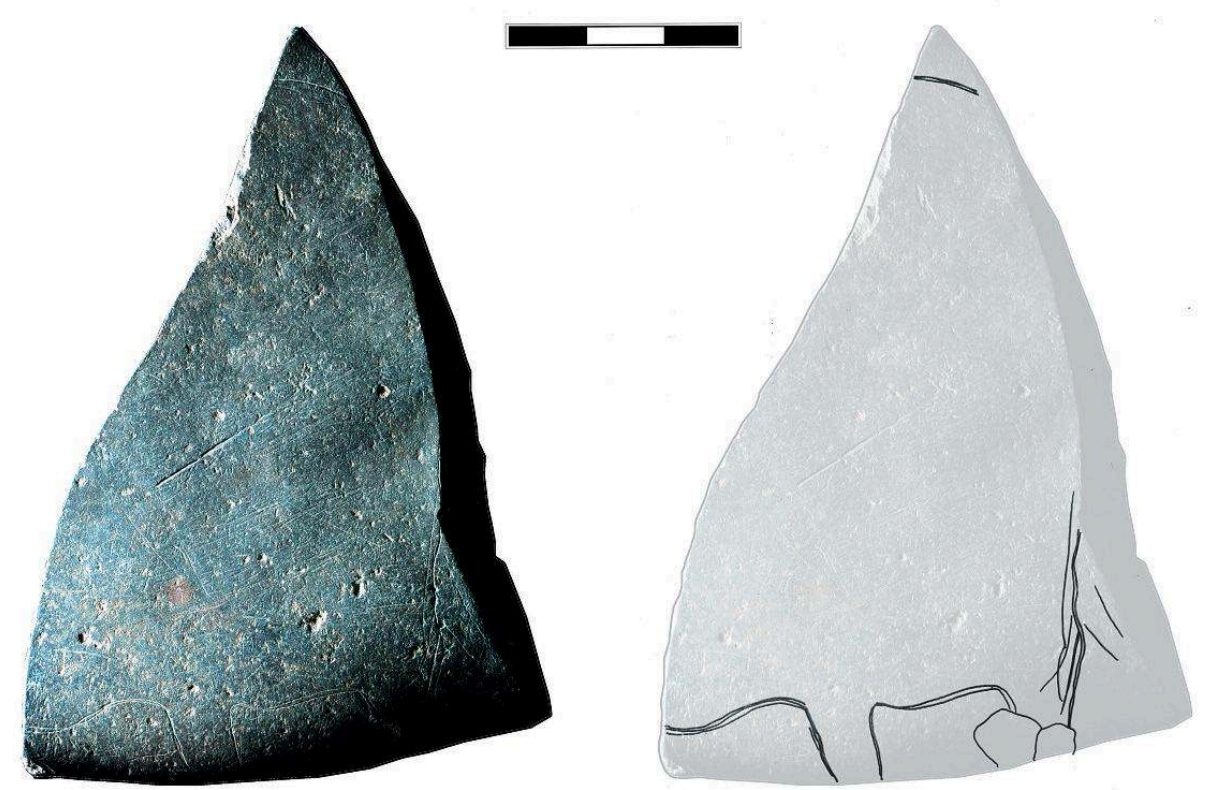




\section{Ist.III. MAN 84859 (fig. 12)}

Figure 12 - Pebble Ist.III. MAN 84859. Photograph and tracing of the engraved figures.

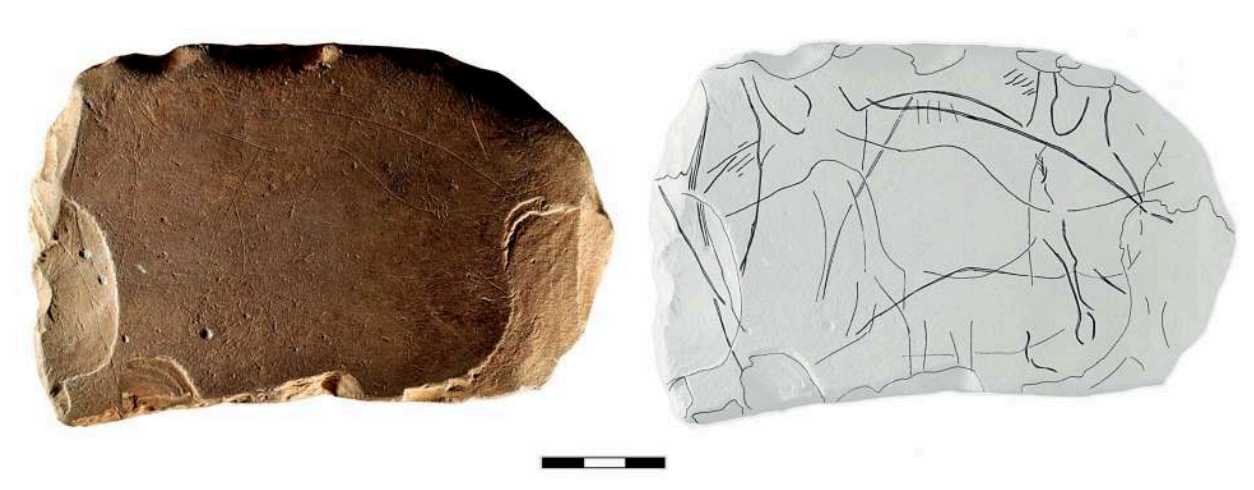

Ist.III. without number (No. 4) (fig. 13)

Pebble engraved on its upper face, with negatives of removals and traces of impacts on the edges. The engravings cover the negatives of removal.

The pebble shows several patterns among which the figure of a quadruped with the four legs, the lines of the stomach and chest.

Opposed and reversed to this figure, is another animal of which only a hind leg with the hoof and hock, and a possible ventral line, a front leg and the chest, were represented.

Other lines, including two possible legs and hatches, complement the decoration of the pebble.

Plaquette engraved on one of its two faces, fragmented after decoration.

The fragmentary condition prevents the determination of the figures. A quadruped can be seen for which only one front leg and a line of hatching were figured.

A second engraved figure stands out with a hind leg, a stomach line and the beginning of the rump.

Figure 13 - Slab Ist.III. Without number $\left(n^{\circ} 4\right)$. Photograph and tracing of the engraved figures.

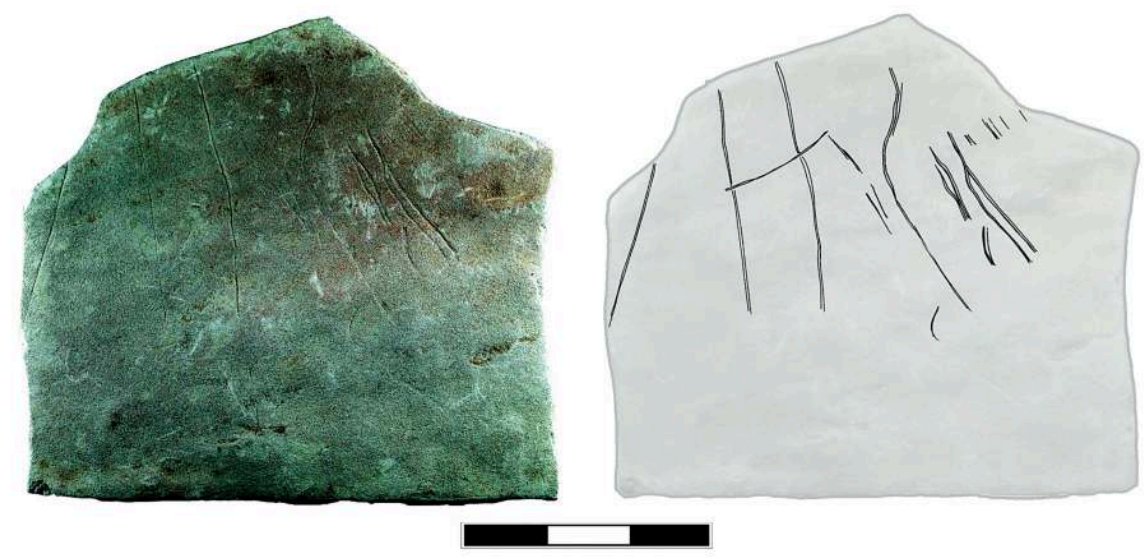




\section{Ist.III. without number (9) (fig. 14)}

\section{Figure 14 - Pebble Ist.III. Without number ( $\left.n^{\circ} 9\right)$. Photograph and tracing of the engraved figures.}
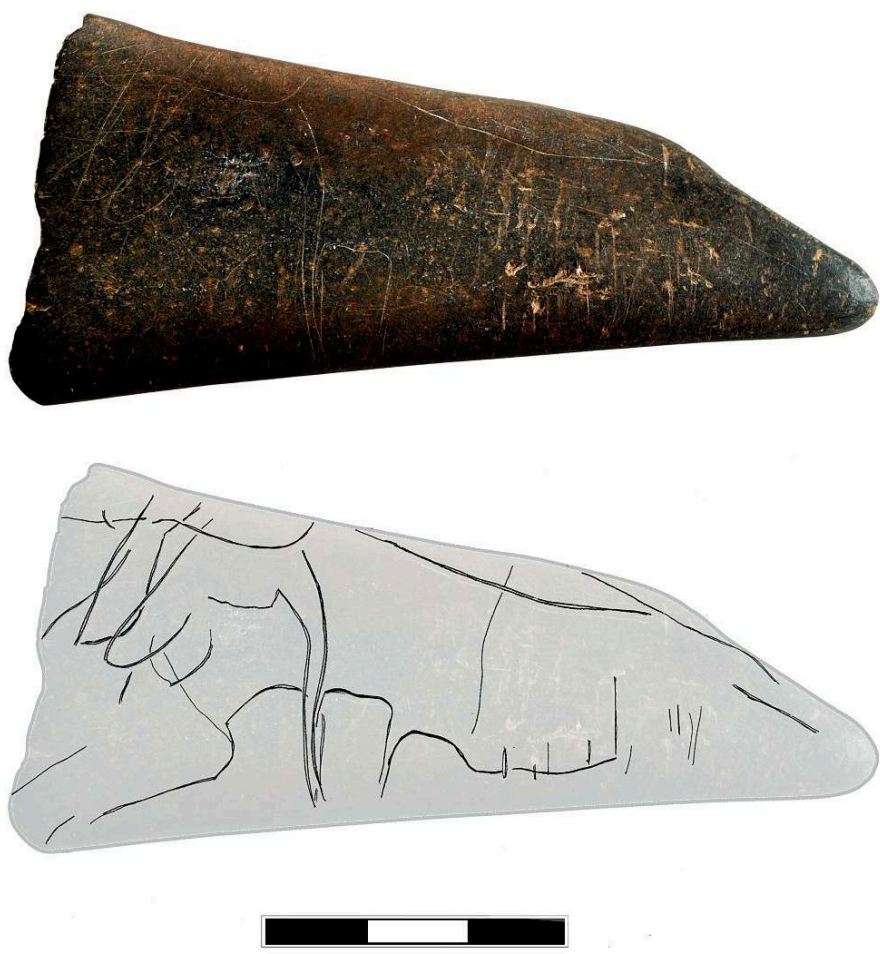

Ist.III. without number (No. 19) (fig. 15)

Pebble engraved on one of its two sides, with many negatives of removals all around and covered with ochre. A fragmentary pattern was kept with
part of an undetermined quadruped. 
Figure 15 - Pebble Ist.III. Without number ( $\left.n^{\circ} 19\right)$. Photograph and tracing of the engraved figures.
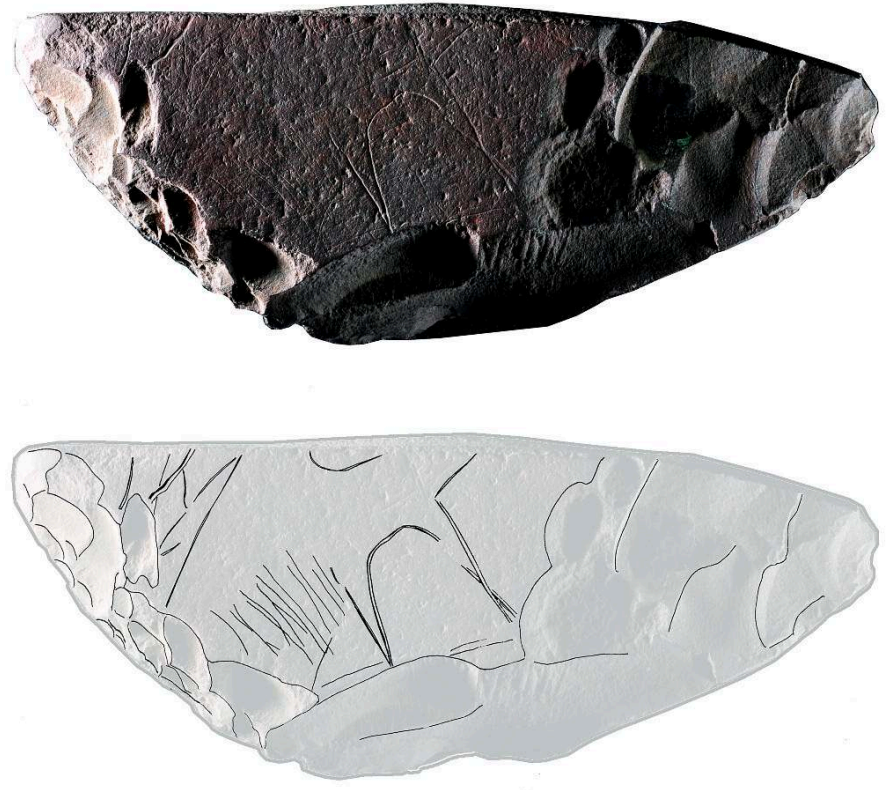

\section{Ist.IV. MAN 84866 (fig. 16)}

Plaquette engraved on one of its two faces. Fractured. The two patterns are vestigial but remain identifiable. The upper part of the forequarters of a small mammoth, with only the head and the beginning of the hump preserved, was done first. One can note the peculiarity of the contour line which is represented by small lines figuring the coat; we also note an eye.

A trunk, whose prehensile end is visible, makes the second pattern. 
Figure 16 - Slab Ist.III. MAN 84866. Photograph and tracing of the engraved figures.
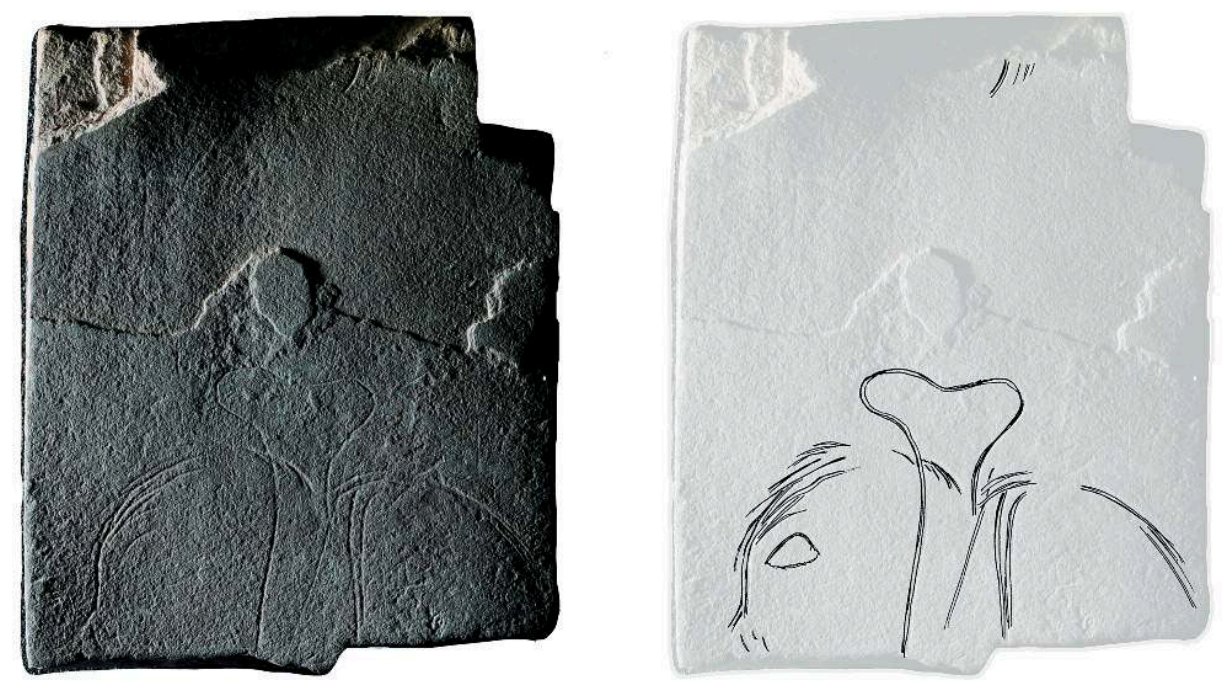

\section{Ist.IV. MAN 84867 (fig. 17)}

61 Fractured pebble, engraved on both sides, with negatives of removals.

62 On the upper side, a fragmented figurative pattern can be identified. This is a bovine for which only the frontal-nasal line, the muzzle and the two horns were represented. Other lines on this surface, among which hatches and straight lines, do not seem to be related to this figure.

63 On the lower side, three indeterminate figurative patterns are visible. They are, first, the hindquarters of a quadruped facing right, with its tail, the end of the cervicaldorsal line and both hind legs in frontal perspective.

Perpendicularly superimposed on this figure, a lower part of hindquarters of a possible artiodactyl, of which two legs with cloven hoof, the dewclaw and the hock, still in frontal perspective and part of the line of the stomach.

Finally, a figure also fragmentary and indeterminate is formed by an eye, hatch lines and a muzzle end with the nostril. 
Figure 17 - Pebble Ist.IV. MAN 84867. Photograph and tracing of the engraved figures.

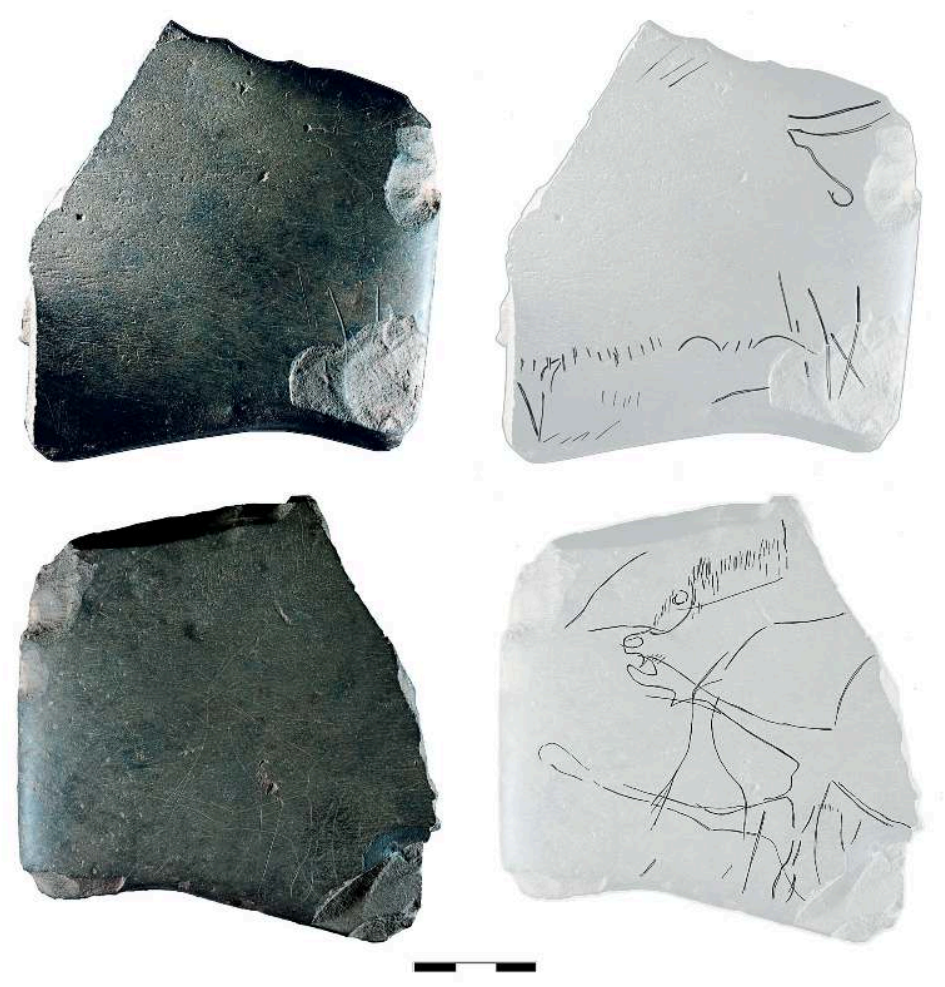

Ist.IV. MAN 84868 (fig. 18)

Pebble engraved on one of its two faces, with negatives of removal over its entire circumference.

Several tangled fragmentary figures are visible on the decorated face, following the same pattern as the other objects.

We can distinguish the figure of a nearly complete bison facing left, for which the line of the cervical-dorsal outline, the tail, the two hind legs in frontal view were indicated with the hock, stomach line formed by an incision and hatching, the two front legs in frontal perspective and hatching that conform the beard of the animal. The head and horns cannot be identified because of the tangle of multiple lines on the left of the pebble.

Under this figure, two legs, with hatching which could represent a beard and a stomach line are visible.

Finally, opposed to this figure and reversed, another figure of quadruped with only the two front legs, the line of the stomach and the two hind legs figured. 
Figure 18 - Pebble Ist.IV. MAN 84868. Photograph and tracing of the engraved figures.

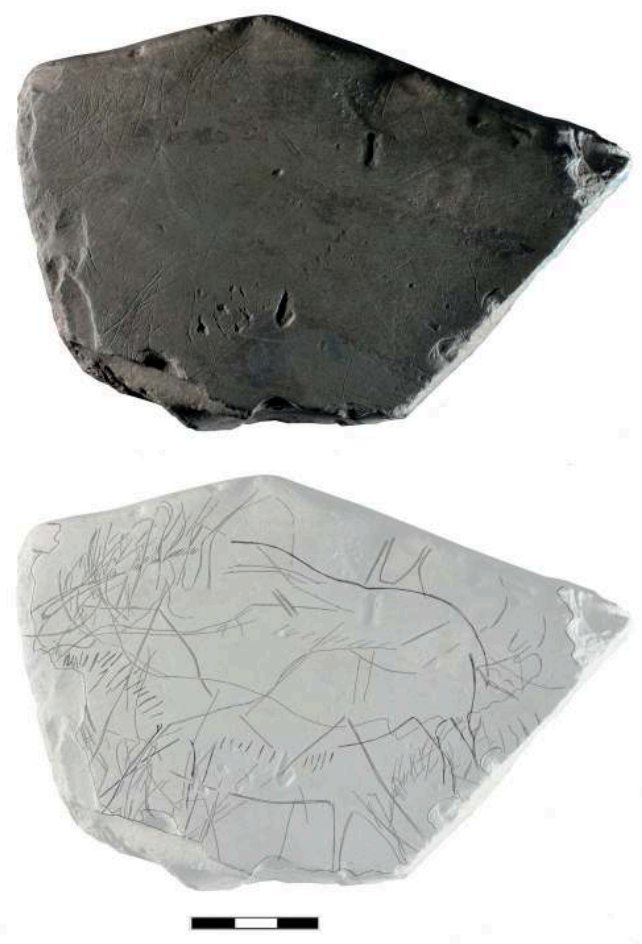

\section{Ist.IV. MAN 84869 (fig. 19)}

71 Whole pebble engraved on both sides, used as a compressor on both sides. Only the upper face has figurative engravings.

These are fragmentary representations. We can distinguish a bovine head, an isolated leg with the hoof and dewclaw, two legs, also isolated, and a last hind leg with the stomach and hock indicated. None of the parts seems to belong to the same figure, and in this case, this is not due to the fragmentation of support.

One can notice the presence of a zigzag associated with the isolated leg, a detail that is found on several figures to represent the coat. 
Figure 19 - Pebble Ist.IV. MAN 84869. Photograph and tracing of the engraved figures.
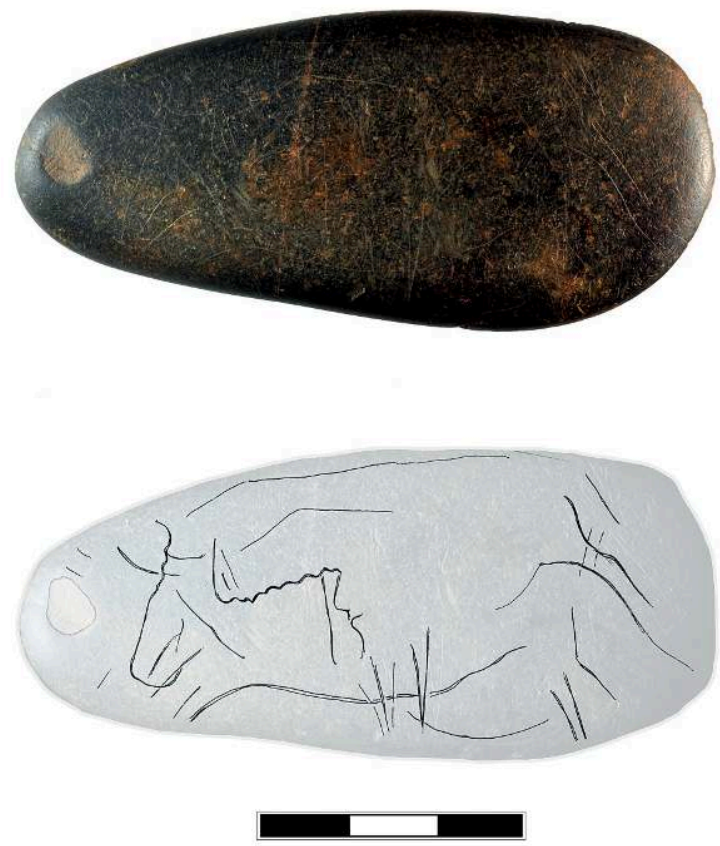

Ist.IV. MAN 84870 (fig. 20)

Neocortical pebble flake engraved on one of its two faces. Negatives of other prior removals are visible on the object.

Amid many lines without identifiable pattern, two fragmentary front legs can be recognized, with the coat and dewclaw indicated, and a line of hatching corresponding to a chest. 
Figure 20 - Flint Ist.IV. MAN 84870. Photograph and tracing of the engraved figures.

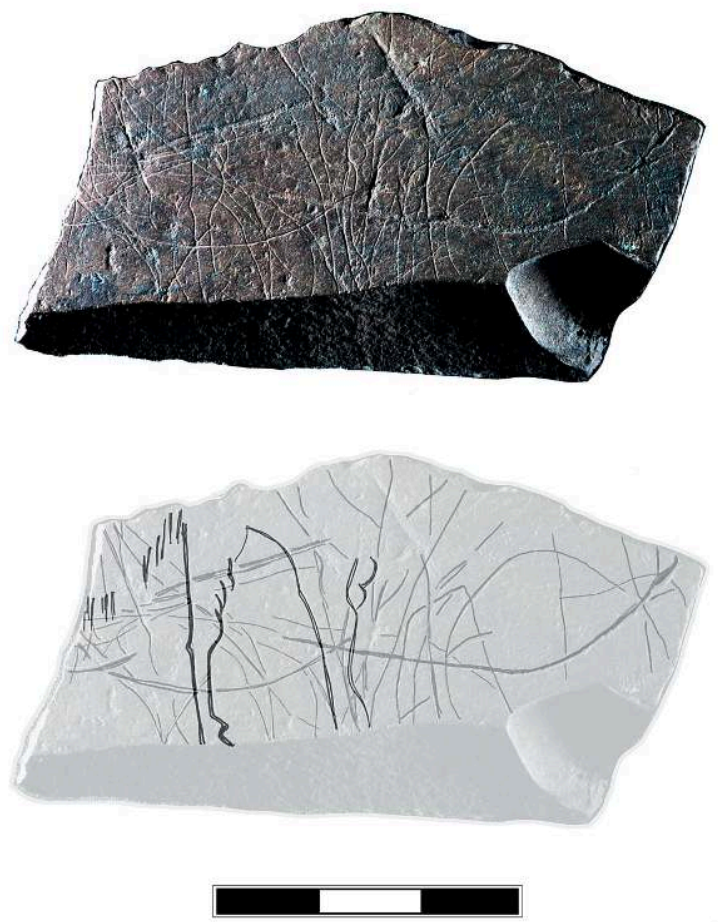

\section{Ist.IV. MAN 84871 (fig. 21)}

Plaquette engraved on one of its two faces. Part of the engravings is lost due to the flaking off of the plaquette.

77 A single figure is readable. This is an artiodactyl quadruped. Only part of the cervicaldorsal line, the tail, the two hind legs with cloven hooves and hock, and the stomach line are preserved. Some hatching could figure the coat of the chest. This is most likely a figure of Equine, possibly a pregnant mare, because of its protruding stomach. 
Figure 21 - Slab Ist.IV. MAN 84871. Photograph and tracing of the engraved figures.
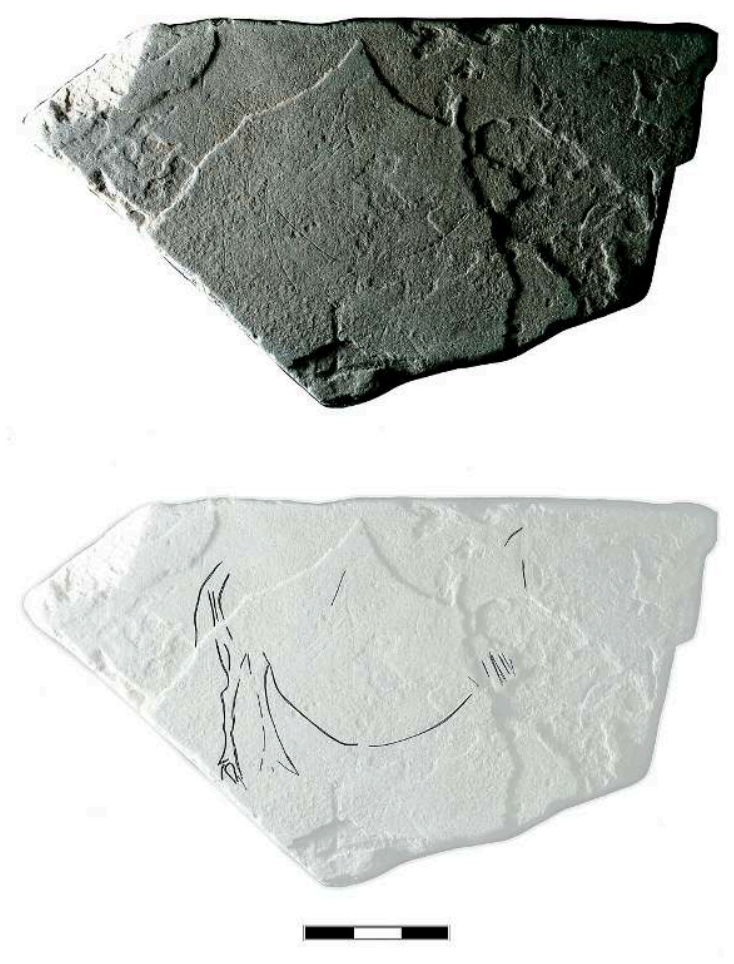

Ist.IV. MAN 84874 (fig. 22) of removal hindering the reading of the pattern. It was figured with antlers in frontal perspective, the head without a muzzle, the eye, the line of the chest, the two front legs frontal perspective, the stomach line that continues into the negatives of removal, and part of the cervical-dorsal line.

A figure of Equine is located on the lower side. We recognize the head with nostrils, a hatched mane and the chest line that extends to the front leg. Other lines do not seem to have any connection with this figurative pattern. 
Figure 22 - Pebble Ist.IV. MAN 84874. Photograph and tracing of the engraved figures.
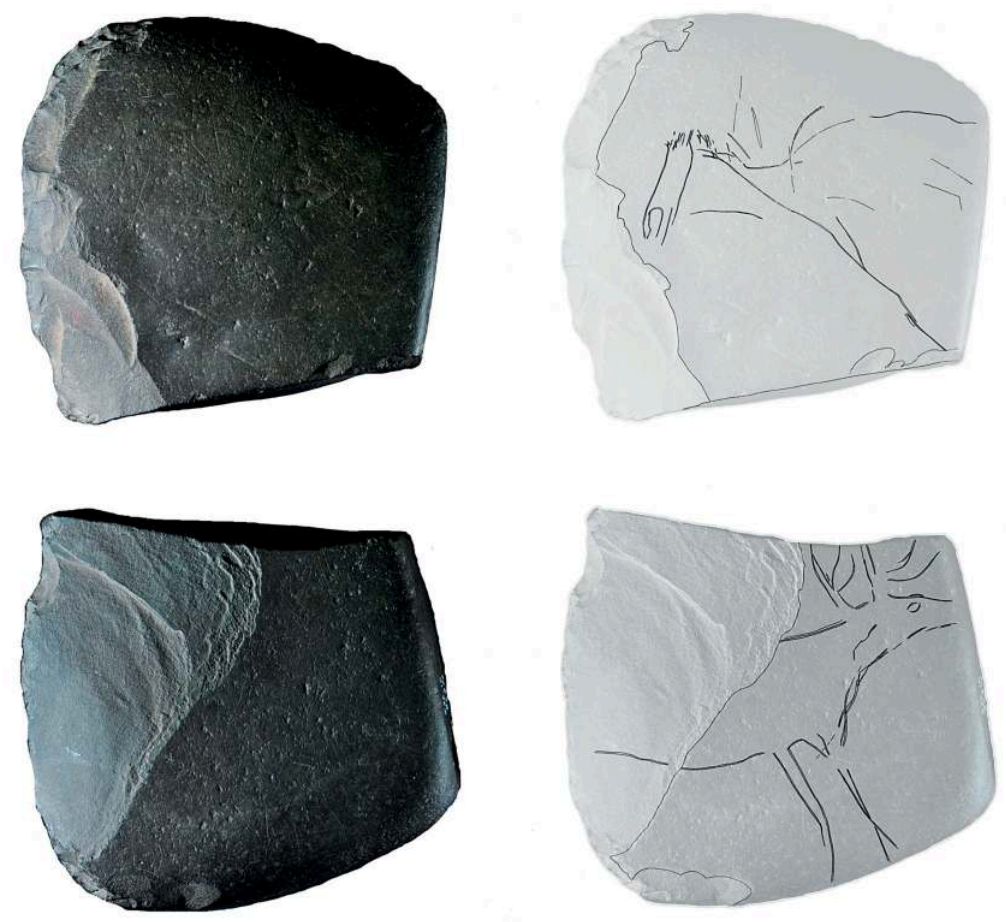

Ist.IV. without number (No. 18) (fig. 23)

81 Fractured pebble, engraved on one of its two faces and with negatives of removals.

82 A quadruped, with only the hindquarters preserved, is featured on the upper side. It has a cervical-dorsal line, a tail, two legs in frontal view and a stomach line.

83 Below this figure, another isolated leg associated with a stomach line could be part of another incomplete pattern. 
Figure 23 - Pebble Ist. IV. Without number ( $\left.n^{\circ} 18\right)$. Photograph and tracing of the engraved figures.

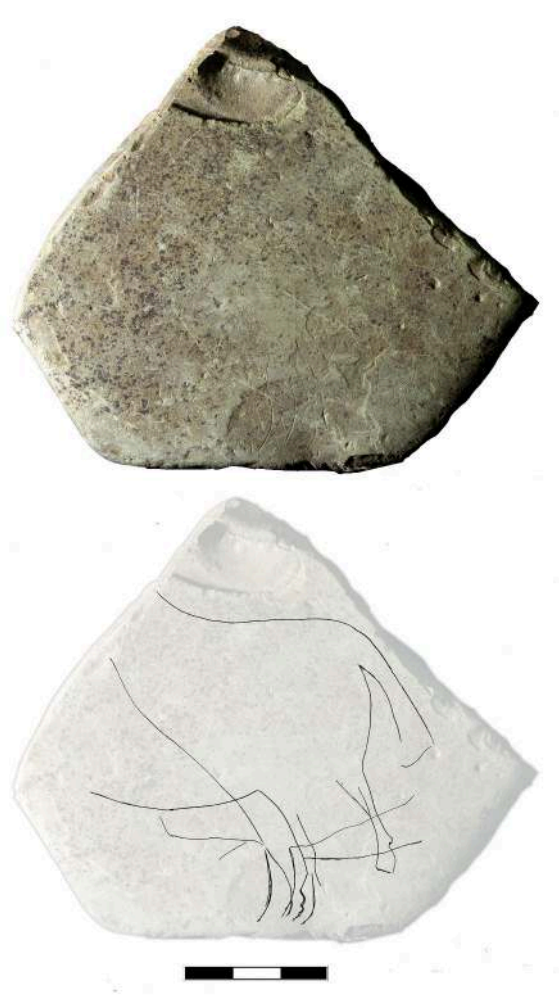

Ist.s.III. without number (No. 24) (fig. 24)

This pebble was found among other objects without context. A handwritten inscription indicated "Isturitz, with the material from level s.III."

Its characteristics are to be compared with other parts of the collection, which has led us to consider it as part of the same group.

It is a pebble decorated on one of its two sides, with several negatives of removals on its circumference and traces of deep impacts superimposed to the engraved lines.

Several entangled figures were engraved on the upper face. We can distinguish a whole deer with circles inside, antlers, legs in frontal view and small head disproportionate with regard to the rest of the body. Another probable figure of quadruped is identifiable by the front legs, the line of the stomach and chest and the cervical-dorsal line. However, the head and the possible tail are in high disproportion with the rest of the figure.

Other lines do not seem to belong to figurative patterns. 
Figure 24 - Pebble Ist. s.III. Without number $\left(n^{\circ} 24\right)$. Photograph and tracing of the engraved figures.

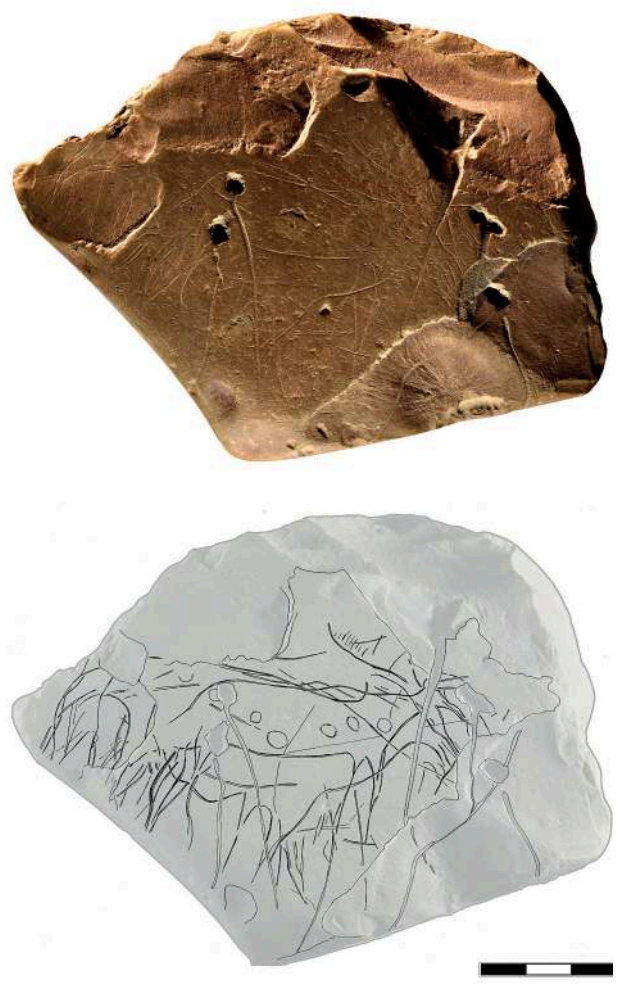

\section{E. Passemard collection}

Ist.C. MAN 75202 (fig. 25)

Engraved plaquette on one of its two faces, fractured into two pieces. Ochre remains are visible inside the engraved lines.

A single figure was represented. It is a mammoth, fragmentary because of the breakage of the support. The head, part of the cervical-dorsal line, the trunk, mouth, the front leg and the stomach line are present. The small size of the trunk, the lack of tusk and also the arched stomach line present outstanding formal characteristics. 
Figure 25 - Slab Ist.C. MAN 75202. Photograph and tracing of the engraved figures.

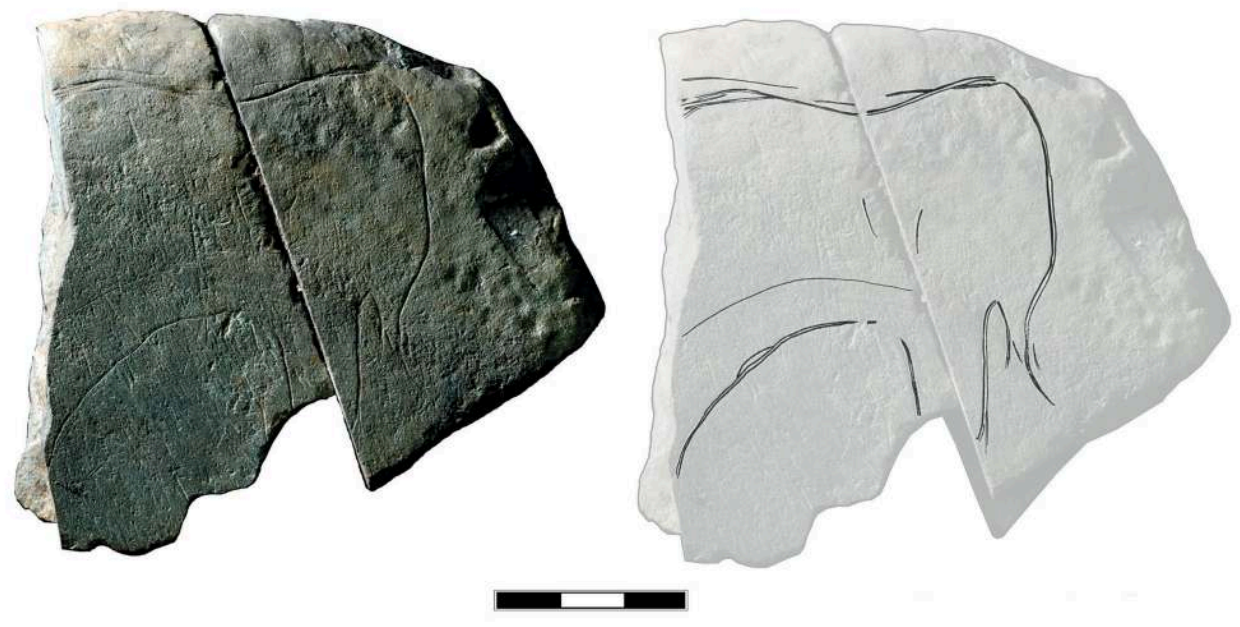

Ist.C alfa. MAN 74835 (fig. 26) except two legs of quadrupeds that were probably part of a pattern truncated due to the breakage of support.

Figure 26 - Pebble Ist. C alfa. MAN 74835. Photograph and tracing of the engraved figures.

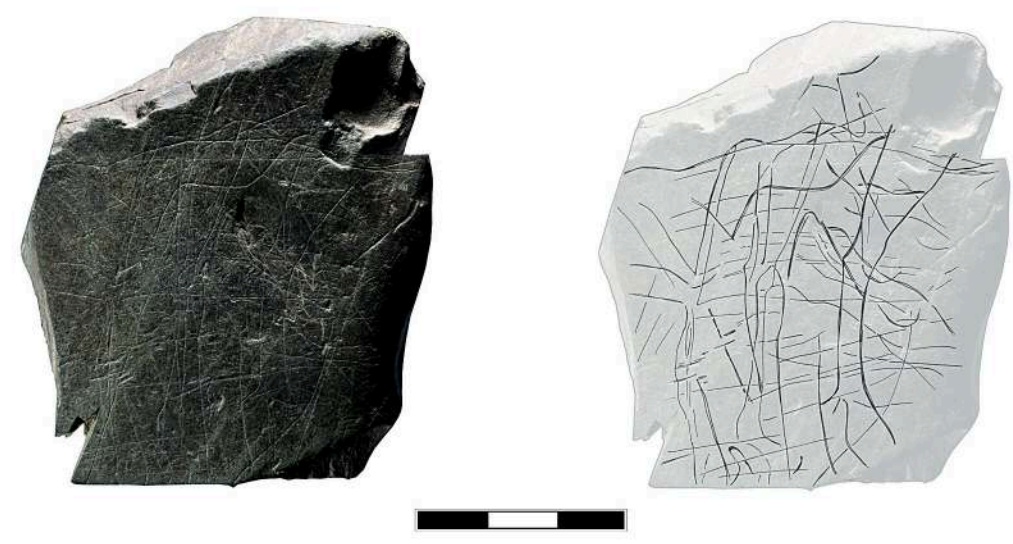

\section{Ist.F2 lower. MAN 75228 (fig. 27)}

Whole pebble, engraved on both sides, used as a compressor on both sides and with negatives of removals.

Two intertwined animals have been represented on the upper side. For each of them, there is the head with the open muzzle, and a line corresponding to the line of the jaw and the line of the chest. This figure does not correspond exactly to the reading done by E. Passemard (1944), who mixes the two. 
Figure 27 - Pebble Ist. F2 inférieur. MAN 75228. Photograph and tracing of the engraved figures.

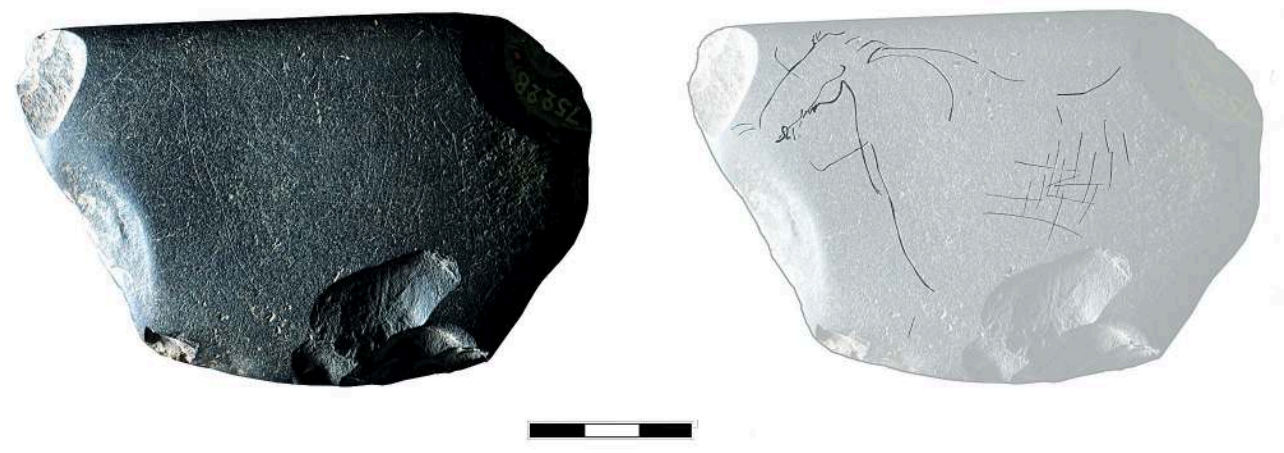

\section{2 - Summary (table 1)}


1997: 81-82). These processes appear in all cases synchronic, the engravings being subsequent to the use, but also affected by these traces and by the functional breakage.

Another feature of the group is the superimposition of the decorations, which creates very intricate sets of engraved animal figures, complete or fragmentary, in every direction. In this regard, the Ist.IIIa without number (No. 11) (fig. 5) pebble is particularly representative.

From a technical perspective, the figures have the same characteristics: incisions with $\mathrm{U}$ profile, or $\mathrm{V}$, more rarely $\mathrm{W}$, the result of one passing of the tool in most cases, and without variation within the figure. Many accidents in the making are present due to a lack of care, which is visible for example in the configuration of the eyes and in the involuntary departures of the tool (fig. 28). However, there are also figures made with great precision, which indicates that these errors are not due, in most cases, to a lack of experience from the authors (Rivero 2011), unlike what was previously stated by R. de Saint-Perier (1952).

From the formal point of view, as well as technically, there is also a high homogeneity in the characteristics of the figures: bovines, deer and mammoths follow conventions.

In the case of bovines, the main features are the twisted or semi-twisted perspective of the horns, the vision of the legs in frontal view, ball-shaped hooves, representation of the coat by hatching, the bump, beard and sometimes the legs, the representation of genitals and the representation of movement in the legs, tail, etc. (fig. 29).

106 As regards to mammoths, they are figures that appear with the most notable attributes such as the presence of a prehensile trunk, anal flap, tusks continuing the trunk or ballshaped legs. The legs in frontal view are also characteristic and share features with the rest of the quadrupeds' figurations (fig. 30).

107 Finally, for deer, one can notice the representation of the legs with a cloven shoe and the dewclaw, the frontal view of the antlers and legs, and occasionally the representation of circles within the figures (fig. 30) .

108 The count of the figures shows a preponderance of bovines, especially bison, followed mammoths, horses and deer. Indeterminate animals are very numerous because of the state of fragmentation of the supports (tab. 2). 
Table 1 - Inventory of Gravettian portable art on lithic support from Isturitz cave.

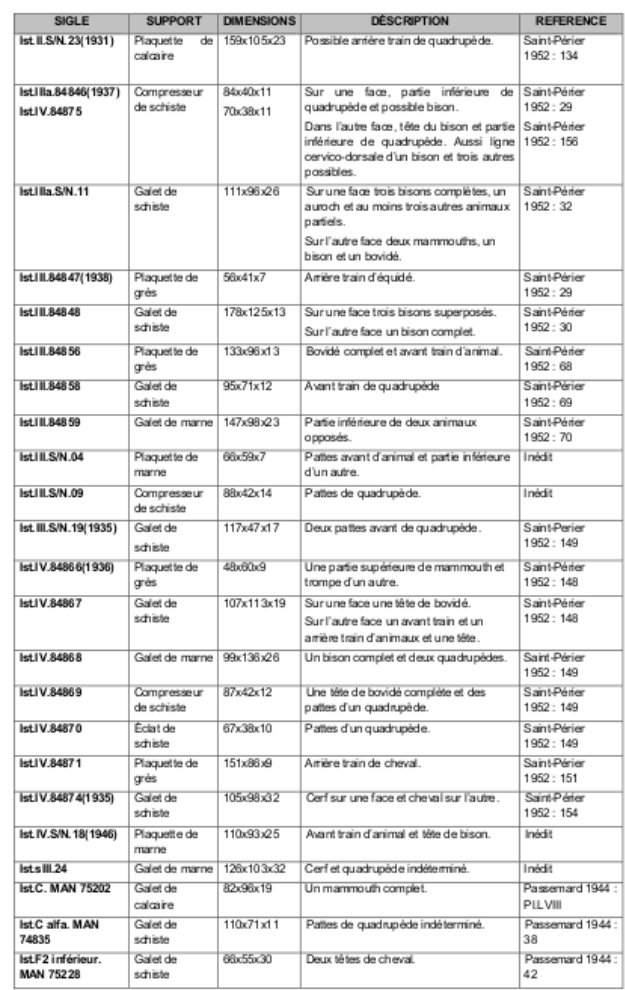

Figure 28 - Some examples of the features of the Gravettian engraved pebbles. a) MAN 84867. Outputs of the tool in the realization of a leg (10x) b) MAN 84848. Example of the not very neat realization of an eye with outputs of the tool (10x) c) MAN 84846. Features of flat profile and only one passage in the realization of two legs (10x) d) MAN 84848. Features in W profile engraved from right to left in the muzzle and the mouth of a bison, due to only one passage (10x).
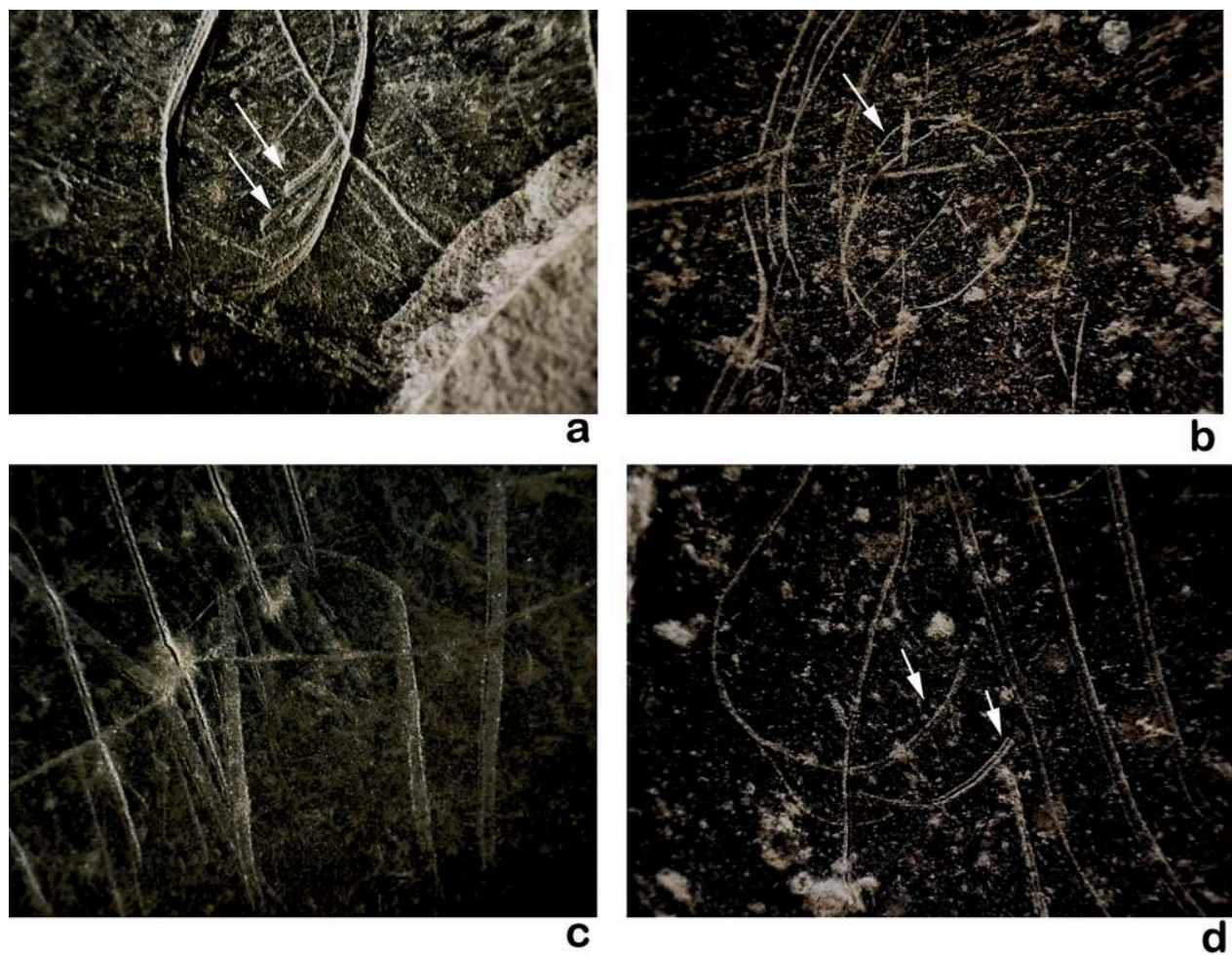


\section{3 - The Gravettian art context}

homogeneity and can be attributed in the most part, to the Gravettian levels from the Grande Salle Isturitz. The animal figures are part of a stylistic trend (thematic, formal conventions, associations, etc.) which is increasingly strengthened by the new discoveries of parietal art in Cussac (Aujoulat et al. 2002) and Cosquer (Clottes, Courtin, Vanrell 2005). Parallels between these groups and other already known like in Gargas, Roucadour or Pech Merle, can be made: the presence of thematic characteristics (female figures), conventions (tusks starting from mammoths trunks, legs of quadrupeds in frontal view, etc.) (Lorblanchet 2001).

111 As for the portable art, the links are, for now, much fewer, beyond the schist plaquette from Gargas (Breuil 1953) and four other plaquettes from the revision of the old collections from the same cave, currently under study (San Juan-Foucher, 2012).

If we try to summarize the various aspects that characterize the art of these caves, we find a very coherent whole (Garate, González-Sainz, 2012), within which the engraved pebbles and plaquettes of Isturitz that we have just presented fit to perfection.

- From a formal point of view, the presence of "double $Y$ " shaped legs and represented on a single plan for quadrupeds, is a characteristic convention of all these groups we also noticed systematically in the case of Isturitz. This convention is also found in the portable art of Parpalló (Villaverde Bonilla 1994).

- The representation of the horns in twisted perspective for the bison of Isturitz is also a widespread formal convention for bison and ibex in Cussac as well as in Gargas, Roucadour, Cosquer and some figures of the Trois-Frères.

- Female profile figurations that, for now, are only found in Pech Merle and Cussac, can be considered as exceptional. They are found associated with mammoths and circular and meandering signs. These mammoths have, in some cases, hatching fillings. The tusks emerge, in all cases, from the trunk and not from the mouth (Lorblanchet 2001), something we have also noticed on the Isturitz portable art.

- - The circular signs (Pech Merle, Roucadour, Gargas and Cosquer), the fallen men (Pech Merle and Cosquer) and the hands stencils (Gargas, Pech Merle, Trois-Frères, Roucadour and Cosquer) are other patterns associated in these caves but are not found in the case of Isturitz. 
Figure 29 - Some exemples of bovids represented in the Gravettian portable art of Isturitz.
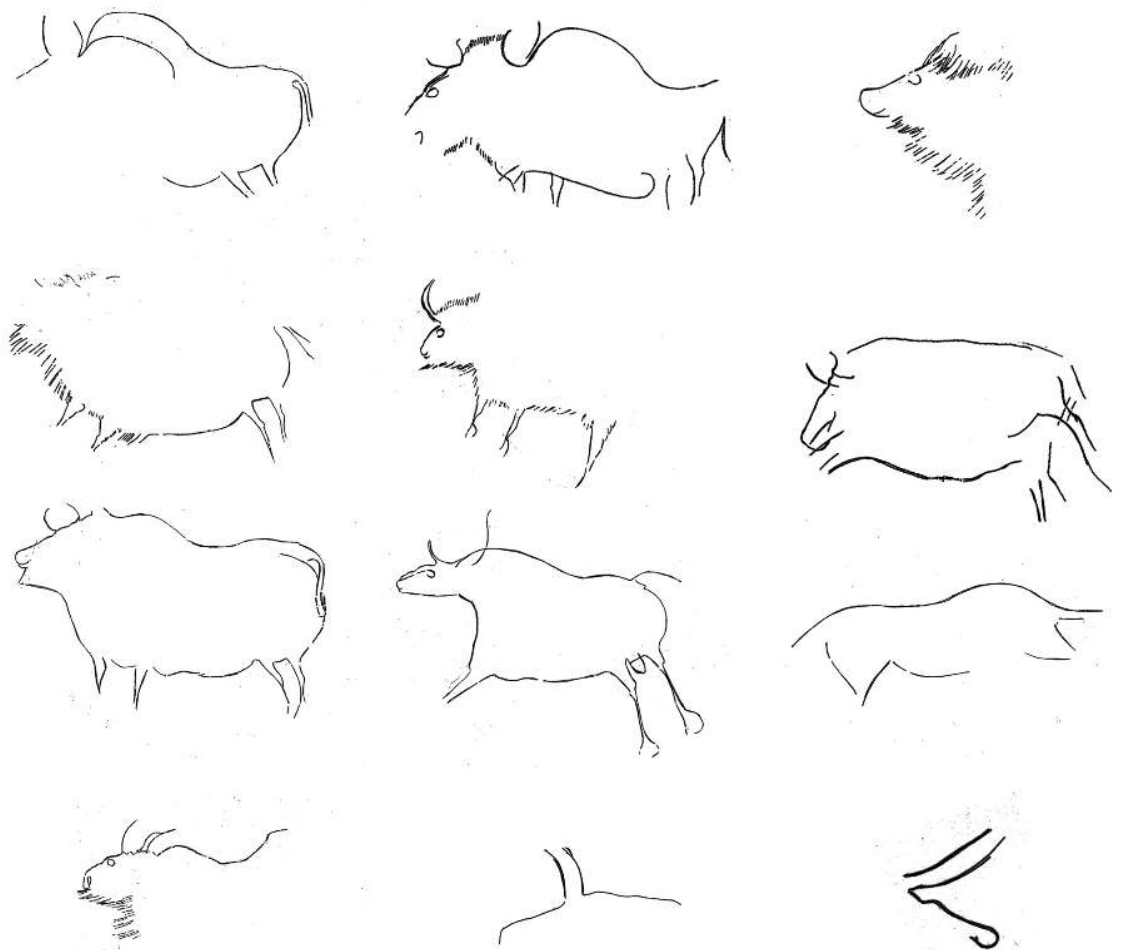

Figure 30 - Mammoths, horses and cervids represented in the Gravettian portable art of Isturitz.
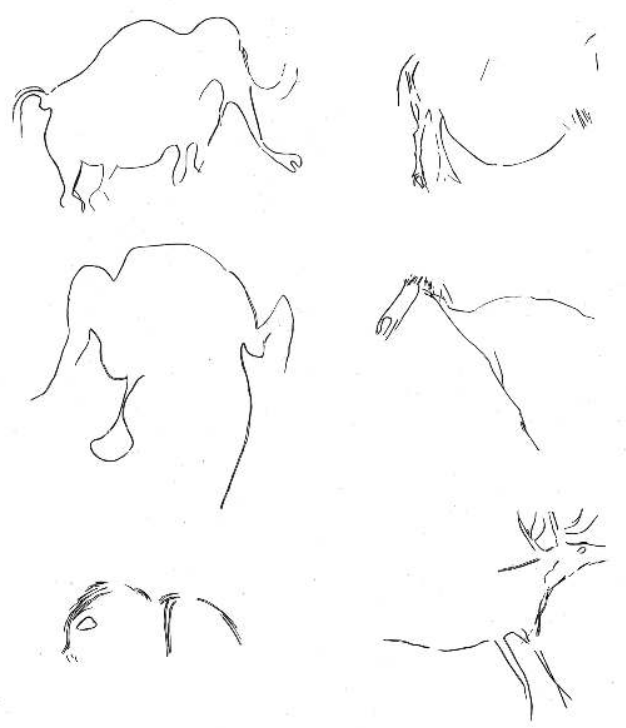<smiles>C=NC</smiles>

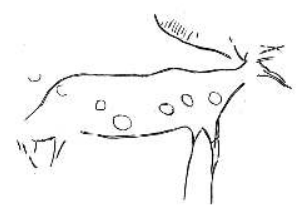


Table 2 - Animal topics identified in the collections.

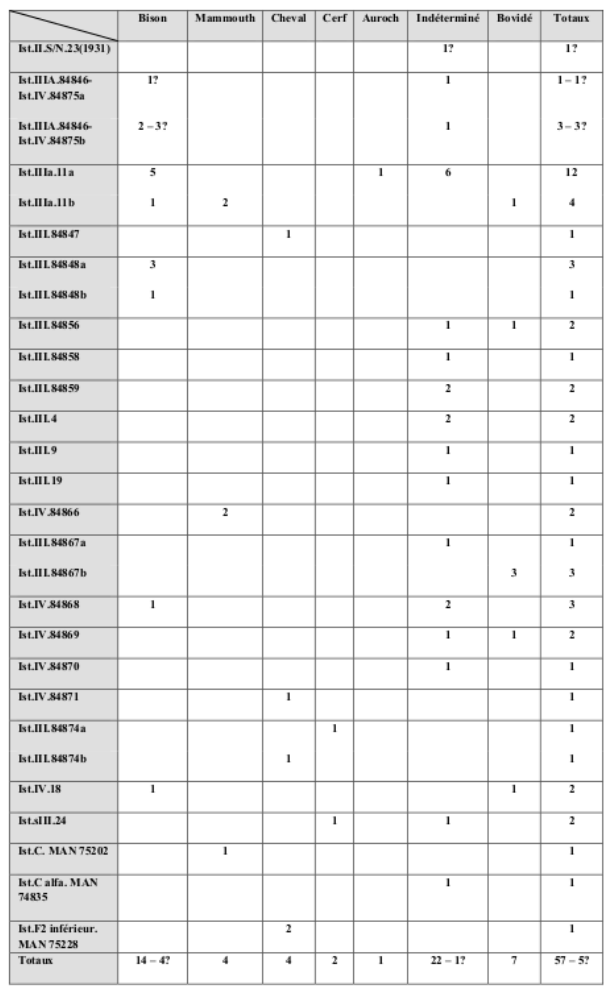

Figure 31 - Bison representations : 1 Roucadour (Glory, 1964), 2-6-7-8 Gargas (Barrière 1976), 3-4-5 Cussac (Aujoulat et al. 2002), 9-10-11 Cosquer (Clottes et al. 2005).
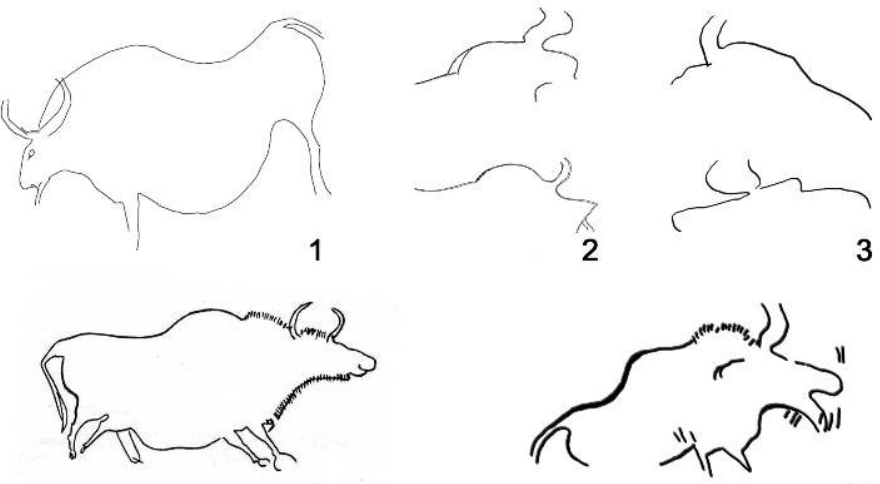

4

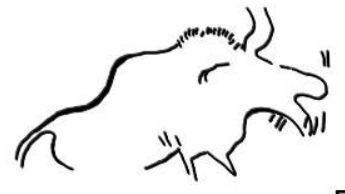
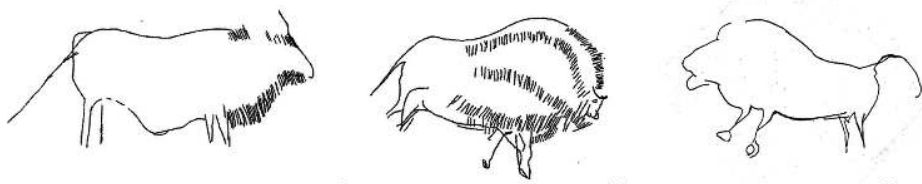

7

8

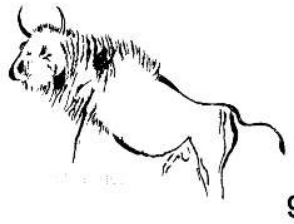

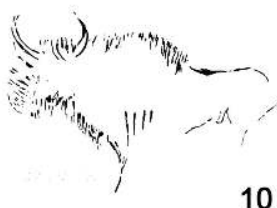<smiles>CCCC(CC)(CC)CC</smiles>

10 
Figure 32 - Mammoth representations : 1 Cussac (Aujoulat et al. 2002), 2 Gargas (Barrière 1976), 3 Roucadour (Glory 1964), 4 Rocaudour (Lorblanchet 2011), 5-6 Pech Merle (Lorblanchet 2011).

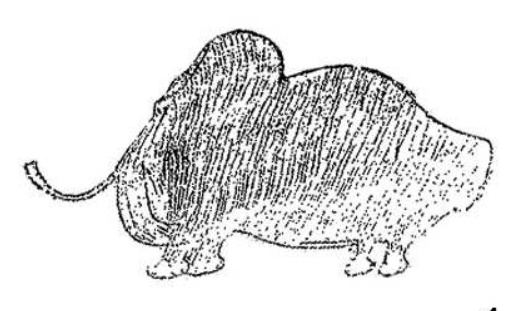

1

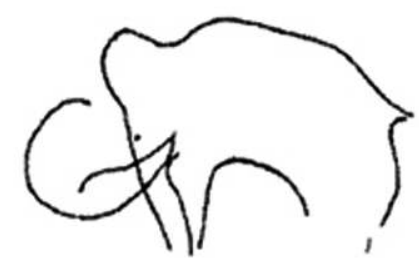

3

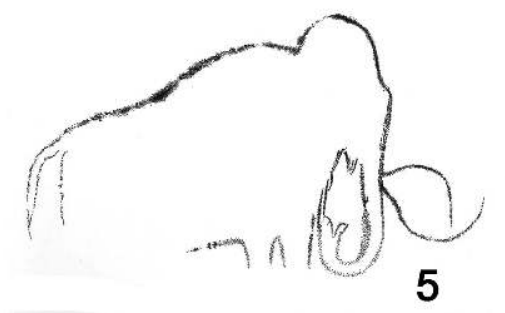

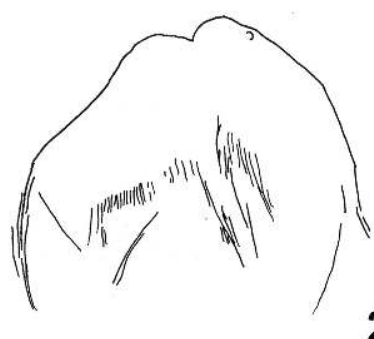

2

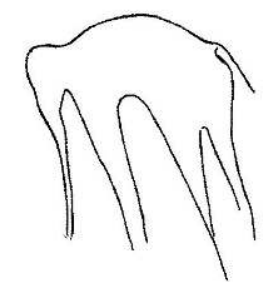

4

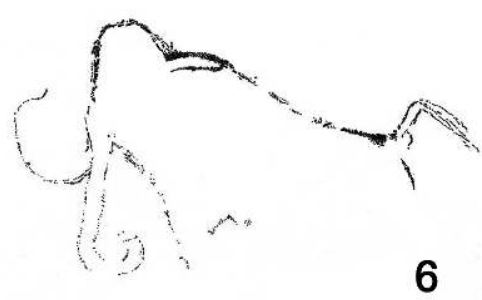

\section{4 - Conclusion}


Isturitz, Gargas, Trois-Frères, Roucadour, Pech Merle, Cussac and even Cosquer. At Gargas, a significant proportion of distant origin flint (up to the Dordogne and the southern side of the Pyrenees) was found in recent excavations.

117 It is the same for circulating bone tools, mainly the "Isturitz type" spears from the Gravettian levels of Gargas, Isturitz or more sites of the Dordogne (Foucher 2005/2006).

Isturitz participates in these socioeconomic and symbolic networks that cover the south of France, at all levels. The role of this site remains to determine in relation to the diffusion toward the Cantabrian region. What seems to be evidence for elements of the archaeological record, such as bone morphotypes (spears of "Isturitz type") or Noailles burins, is far less clear in the case of artistic conventions.

The revision of the parietal and portable art of this exceptional collection from Isturitz allows undoubtedly bringing new elements to the discussion about the establishment of exchange networks in the Gravettian in Western Europe.

\section{BIBLIOGRAPHY}

AUJOULAT N., GENESTE J., ARCHAMBEAU DELLUC M., DUDAY H., GAMBIER D. 2002 - La grotte ornée de Cussac - Le Buisson-de-Cadouin (Dordogne): premières observations. Bulletin de la Société Préhistorique Française, 99 (1), p. 129-137.

BARRIÈRE, C. 1976 - L'art pariétal de la grotte de Gargas. BAR International Séries 14, Mémoire de l'Institut d'Art Préhistorique de Toulouse, Oxford.

BEAUNE (de) S. 1997 - Les galets utilisés au Paléolithique supérieur : approche archéologique et expérimentale, Paris, CNRS (Supplément à Gallia Préhistoire 32), 298 p.

BREUIL H. 1953 - Gravures sur schiste périgordiennes de la caverne de Gargas. Bulletin de la Société Royale Belge d'Anthropologie et de Préhistoire, 64, p. 195-212.

BUISSON D. 1990 - Les flûtes paléolithiques d'Isturitz (Pyrénées-Atlantiques). Bulletin de la Société Préhistorique Française, 87 (11-12), p. 420-433.

CROIDIEU E. 2012 - Des fragments de mémoire. Les statuettes animalières de la grotte d'Isturitz (PyrénéesAtlantiques) vers un approche technologique, Lyon, Mémoire de Master 2, Université Jean Moulin Lyon 3, $100 \mathrm{p}$.

CLOTTES J., COURTIN J., VANRELL L. 2005 - Cosquer redécouvert. Seuil, Paris.

ESPARZA SAN JUAN X. 1995 - La cueva de Isturitz, su yacimiento y sus relaciones con la Cornisa cantabrica durante el Paleolítico superior, Madrid, UNED.

FOUCHER P. 2005/2006 - Gargas et l'Atlantique: les relations transpyrénnées au cours du Gravettien. Munibe (Antropologia-Arkeologia), 57 (nº 1), Homenaje a Jesús Altuna, p. 131-147.

GAMBIER D. 1990-1991 - Les vestiges humains du gisement d'Isturitz (Pyrénées-Atlantiques), étude anthropologique et analyses des traces d'action humaine intentionnelle. Antiquités nationales, 22-23, p. 9-26. 
GARATE D., GONZALEZ SAINZ C. 2012 - Las patas en « doble Y » en la iconografía animal del arte parietal paleolítico: una convención gráfica limitada en el tiempo y en el espacio. In: P. Arias Cabal, Corchón Rodríguez, S., Menéndez Fernández, M., Rodríguez Asensio, A. (Eds.): El Paleolítico Superior Cantábrico, Actas de la Primera Mesa Redonda, San Román de Candamo (Asturias) 26-28 de abril de 2007, IIIPC monografías no 3, Santander, p. 225-236

GARATE D., LABARGE A., RIVERO O., NORMAND C., DARRICAU J. 2013 - The cave of Isturitz (West Pyrenees, France): one century of research in Paleolithic parietal art. Arts, 2 (4), p. 253-272.

GLORY A. 1964 - La grotte de Roucadour (Lot). Bulletin de la Société Préhistorique Française, LXL, P. 166-169.

GOUTAS N. 2004 - Caractérisation et évolution du Gravettien en France par l'analyse techno-économique des industries en matières osseuses, thèse de doctorat, université Paris I - Panthéon-Sorbonne, 2 vol., 675 p.

HENRY-GAMBIER D., PÉTILLON J.-M., NORMAND C. 2013 - Datation radiocarbone directe et attribution culturelle des vestiges humains paléolithiques de la grotte d'Isturitz (PyrénéesAtlantiques). Bulletin de la Société Préhistorique Française, 110 (4), p. 645-656.

LACARRIERE J., GOUTAS N., NORMAND C., SIMONET A. 2011 - Vers une redéfinition des occupations gravettiennes de la grotte d'Isturitz (Pyrénées-Atlantiques, France) : révision critique des collections « anciennes " par l'approche intégrée des données lithiques, fauniques et de l'industrie osseuse. In : N. Goutas, L. Klaric, D. Pesesse et P. Guillermin (dir.), À la recherche des identités gravettiennes : actualités, questionnements et perspectives, Paris, Société préhistorique française (Mémoire, 52), p. 67-83

LORBLANCHET M. 2001 - Cussac, fantastique grotte gravée de la préhistoire. Archéologia, 381, p. 4-8.

LORBLANCHET M. 2011 - Art pariétal. Grottes ornées du Quercy. Rouerge. Paris.

LUCAS C. 2012 - Les décors géométriques du Magdalénien supérieur de la grotte d'Isturitz (Pyrénées-Atlantiques) : une place à part dans l'équipement?, in J. Clottes (dir.), L'art pléistocène dans le monde, Actes du Congrès IFRAO, (Tarascon-sur-Ariège, 2010), Symposium « Art mobilier pléistocène ", $\mathrm{N}^{\circ}$ spécial de Préhistoire, Art et Sociétés, Bulletin de la Société Préhistorique AriègePyrénées, LXV-LXVI, 2010-2011, CD, p. 1501-1521.

MONS L. 1986 - Les statuettes animalières en grès de la grotte d'Isturitz (Pyrénées-Atlantiques), observations et hypothèses de fragmentation volontaire, L'Anthropologie, 90, 4, p. 701-711.

MONS L. 1986/1987 - Les figurations de bisons dans l'art mobilier de la grotte d'Isturitz (Pyrénées-Atlantiques). Les particularismes techniques et stylistiques éclairent-ils les processus créatifs? Antiquités Nationales, 18-19, p. 91-99.

NORMAND C. 2005/2006 - Les occupations aurignaciennes de la grotte d'Isturitz (Saint-Martind'Arberoue, Pyrénées-Atlantiques, France) : synthèse des données actuelles. Munibe (AntropologiaArkeologia), 57 ( $\mathrm{n}^{\circ}$ 1), Homenaje a Jesús Altuna, p. 119-129.

NORMAND C., TURQ A. 2006 - Bilan des recherches 1995- 1998 dans la Grotte d'Isturitz (communes d'Isturitz et de Saint-Martin-d'Arberoue, Pyrénées-Atlantiques). In : C. Chauchat (dir.), Préhistoire du bassin de l'Adour : bilans et perspectives, actes du colloque (Saint-Étiennede-Baigorry, 19 janvier 2002), Saint-Étienne-de-Baigorry, Izpegi, p. 69-101.

NORMAND C., GOUTAS, N., LACARRIÈRE, J., SIMONET A. 2012 - El Gravetiense de la cueva de Isturitz: nuevas investigaciones, nuevos datos. In : de las Heras, C., Lasheras, J.A., Arrizalaga, A., de la Rasilla, M. (Ed.), Pensando el Gravetiense: nuevos datos para la región cantábrica en su contexto 
peninsular y pirenaico. Museo Nacional y Centro de Investigación de Altamira, monografías 23, Santander, Madrid, p. 161-183.

PASSEMARD E. 1930 - Une gravure aurignacienne à Isturitz. Bulletin de la Société Préhistorique Française, 27, p. 357-360.

PASSEMARD E. 1944 - La caverne d'Isturitz en Pays Basque. Préhistoire, 9, p. 7-95.

PÉTILLON J.-M. 2004 - Lecture critique de la stratigraphie magdalénienne de la Grande Salle d'Isturitz (Pyrénées- Atlantiques). Antiquités nationales, 36, p. 105-131.

PÉTILLON J.-M. 2006 - Des Magdaléniens en armes. Technologie des armatures de projectile en bois de cervidé du Magdalénien supérieur de la grotte d'Isturitz (Pyrénées- Atlantiques), Treignes, CEDARC (Artefacts, 10), $302 \mathrm{p}$.

PRUDHOMME S. 1989 - L'art pariétal préhistorique des grottes d'Isturitz, d'Oxocelhaya et d'Erberua (Pays Basque). Application de méthodes statistiques à l'art pariétal paléolithique du Pays Basque. Thèse de doctorat, Museum National d'Histoire Naturelle, Paris.

RIVERO O. 2009 - Les représentations de têtes de bison isolées du Magdalénien moyen francocantabrique : analyse des données technologiques et stylistiques. Préhistoire, art et sociétés, 64, p. 175-184.

RIVERO O. 2010 - La movilidad de los grupos humanos en el Magdaleniense cantábrico y pirenaico: Una visión a través del arte, Thèse de Doctorat, Université de Salamanque, Salamanque, 1362 p.

RIVERO 0. 2011 - La noción de aprendizaje en el arte mobiliar del Magdaleniense Medio cántabro-pirenaico: la contribución del análisis microscópico. Trabajos de Prehistoria, 68 (n²), p. 275-295.

RIVERO O. 2014 - Vers une caractérisation du gisement magdalénien d'Isturitz (PyrénéesAtlantiques) à travers sa production artistique. Bulletin de la Société Préhistorique Française, 111 ( ${ }^{\circ}$ 2), p. 255-274.

SAINT-PÉRIER R. (de), SAINT-PÉRIER S. (de) 1930 - La Grotte d'Isturitz, I : le Magdalénien de la Salle de Saint-Martin. Paris, Masson (Archives de l'Institut de paléontologie humaine, mémoire 7), $124 \mathrm{p}$.

SAINT-PÉRIER R. (de), SAINT-PÉRIER S. (de) 1936 - La Grotte d'Isturitz, II : le Magdalénien de la Grande Salle. Paris, Masson (Archives de l'Institut de paléontologie humaine, mémoire 17), 139 p.

SAINT-PÉRIER R. (de), SAINT-PÉRIER S. (de) 1952 - La Grotte d'Isturitz, III. Les Solutréens, les Aurignaciens et les Moustériens, Paris, Masson (Archives de l'Institut de paléontologie humaine, 25), $264 \mathrm{p}$.

SAN JUAN-FOUCHER C. 2012 - Industria ósea decorada y arte mueble del Gravetiense pirenaico: perspectivas territoriales actualizadas. In : de las Heras, C., Lasheras, J.A., Arrizalaga, A., de la Rasilla, M. (Ed.), Pensando el Gravetiense: nuevos datos para la región cantábrica en su contexto peninsular y pirenaico. Museo Nacional y Centro de Investigación de Altamira, monografías 23, Santander, Madrid, p. 461-483.

SIMONET A. 2009 - Les Gravettiens des Pyrénées : des armes aux sociétés, thèse de doctorat, Université Toulouse 2 - Le Mirail, $391 \mathrm{p}$.

SZMIDT C., PÉTILLON J.-M., CATTELAIN P., NORMAND C., SCHWAB C. 2009 - Premières dates radiocarbone pour le Magdalénien d'Isturitz (Pyrénées-Atlantiques). Bulletin de la Société Préhistorique Française, 106 ( $\mathrm{n}^{\circ}$ 3), p. 583-601. 
VILLAVERDE BONILLA V. 1994 - Arte paleolítico de la Cova de Parpalló: estudio de la colección de plaquetas y cantos grabados y pintados. Servei d'Investigació Prehistòrica, Diputació de València, Valencia.

\section{NOTES}

4. Among the objects identified by R. de Saint-Perier as decorated with figurative patterns, the review carried out led us to reject an engraved schist pebble with a "young deer head" (SaintPerier 1952: 151, fig. 83.2) and a sandstone plaquette engraved with a "horse protome" (SaintPerier 1952: 156, fig.86.2).

5. Among the plaquettes published by R. and S. de Saint-Perier, we did not find the following objects in the store rooms of the National Museum of Archaeology: pebble engraved with "human profiles" (Saint-Perier 1952: 32, fig.13.1), perforated pebble, (Saint-Perier 1952: 47 fig.20.8), pebble engraved with "animal hindquarters" (Saint-Perier 1952: 68, fig.31.3), pebble engraved with "human bodies mixed with various figures" (Saint-Perier 1952: 69 fig.32.2), pebble engraved with "human shapes and mammoth" (Saint-Perier 1952: 70, fig.33.4), perforated pebble engraved with "human shape" (St. Perier 1952: 133, fig.71.2), engraved plaquette with an "ibex" (?) (St. Perier 1952: 151 fig.83.3), plaquette engraved with a "deer head, with horns or legs" (Saint-Perier 1952: 153, fig.84.4). S. de Beaune mentions an Aurignacian pebble in layer V, decorated with a possible bird head, which we did not find again (de Beaune 1997, 239, pl. 29: 148).

6. We gave a numbering to the non-numbered objects in the Saint-Perier collection.

\section{ABSTRACTS}

The archaeological site of the cave of Isturitz (Pyrénées-Atlantiques) is especially known by the quantity and the importance of its Magdalenian portable art. But the decorated supports from the Solutrean, Gravettian and Magdalenian levels are largely ignored, particularly those from Saint-Périer excavations which offered a rather significant number of decorated objects.

This work is a part of the result of the revision carried out on the collections preserved at the Museum of National Archaeology, resulting from the excavations from R. and S. de Saint-Périer and E. Passemard.

This revision enabled us to renew the documentation of premagdalenian portable art of Isturitz, by revealing many figurative and nonfigurative representations, whose formal characteristics are very homogeneous and directly related to the Gravettian parietal figurations of caves like Cussac, Gargas, Cosquer or Roucadour. Only animal figures are treated in this paper.

The data rassembled allows to linking the portable artistic production of Isturitz with formal models which are developed throughout France during Gravettian, without reaching, in the actual position of our knowledge, the Iberian Peninsula.

Le site archéologique de la grotte d'Isturitz (Pyrénées-Atlantiques) est spécialement connu pour la quantité et l'importance de son art mobilier magdalénien. En ce qui concerne les supports ornés des niveaux solutréens, gravettiens et aurignaciens, ils sont largement méconnus, particulièrement ceux correspondant aux fouilles de Saint-Périer qui ont livré un nombre assez significatif d'objets décorés. 
Ce travail présente une partie des résultats de la révision effectuée sur les collections conservées au Musée d'Archéologie Nationale, issues des fouilles de R. et S. de Saint-Périer et E. Passemard. Cette révision nous a permis de renouveler la documentation de l'art mobilier antémagdalénien d'Isturitz, en révélant un ensemble très fourni de représentations figuratives et non figuratives, dont les caractéristiques formelles, très homogènes, sont directement liées aux figurations pariétales gravettiennes des grottes contemporaines comme Cussac, Gargas, Cosquer ou Roucadour. Nous n'évoquerons ici que les figures animales.

Les données rassemblées permettent de lier la production artistique mobilière d'Isturitz avec des modèles formels qui se sont développés en France pendant le Gravettien, sans atteindre, dans l'état actuel de nos connaissances, la Péninsule Ibérique.

\section{INDEX}

Mots-clés: Isturitz, art mobilier, Gravettien, bison, mammouth

Keywords: Isturitz, portable art, Gravettian, bison, mammoth

\section{AUTHORS}

\section{OLIVIA RIVERO}

TRACES (UMR 5608), CREAP, Université Toulouse 2 le Mirail, Maison de la Recherche, 5, allée Antonio Machado, FR-31058 TOULOUSE CEDEX 9 - oliviariver@hotmail.com

\section{DIEGO GARATE}

Arkeologi Museoa, Calzadas de Mallona s/n, ES-48006 BILBAO - garatemaidagandiego@gmail.com 